\title{
The Business Model of Sustainable Competitive Advantage through Strategic Leadership Capabilities and Knowledge Management Processes to Overcome COVID-19 Pandemic
}

\author{
Omar Rabeea Mahdi * and Islam A. Nassar
}

check for

updates

Citation: Mahdi, O.R.; Nassar, I.A. The Business Model of Sustainable Competitive Advantage through Strategic Leadership Capabilities and Knowledge Management Processes to Overcome COVID-19 Pandemic. Sustainability 2021, 13, 9891. https:// doi.org/10.3390/su13179891

Academic Editors: Joon Koh and Sang Cheol Park

Received: 7 July 2021

Accepted: 23 August 2021

Published: 2 September 2021

Publisher's Note: MDPI stays neutral with regard to jurisdictional claims in published maps and institutional affiliations.

Copyright: (c) 2021 by the authors. Licensee MDPI, Basel, Switzerland. This article is an open access article distributed under the terms and conditions of the Creative Commons Attribution (CC BY) license (https:// creativecommons.org/licenses/by/ $4.0 /)$.
Department of Business Administration, College of Administrative Sciences, Applied Science University, East Al-Ekir 623, Bahrain; islam.nassar@asu.edu.bh

* Correspondence: omar.almafrachi@asu.edu.bh; Tel.: +973-1603-6016

Abstract: In recent decades, particularly during the outbreak of COVID-19, businesses organizations have focused on knowledge management processes in order to attain a sustainable competitive advantage by creating human and social capital as strategic leadership capabilities. This paper aims to develop an integrated conceptual and theoretical framework that connects strategic leadership capabilities, knowledge management processes, and sustainable competitive advantage for the public and private organizations within the service industry. The model approach has been used to build a theoretical framework that predicts the relationships between the variables. To support the link between them, a systematic literature review of traditional and contemporary theoretical and empirical research studies is conducted. Through the combination of the related literature, propositions are established. This conceptual research is primarily comprised of a model and assertions concerning strategic leadership capabilities, knowledge management processes, and sustainable competitive advantage. The outcomes of this study reflect that strategic leadership capabilities can accomplish sustainable competitive advantage. They also have the greatest potential to impact sustainable competitive advantage via engaging the knowledge management processes. Particularly, there are significant implications of this study. Regarding the theoretical implication, it contributes to the resource-based view, knowledge-based view, and knowledge creation theory in supporting strategic leadership capabilities, knowledge management processes, and sustainable competitive advantage. To the practical implication, the study linked the concepts of research variables for public and private enterprises within the service industry. It can also enable strategic leaders and businesses owners to participate in real-time opportunities and determine threats for achieving a sustainable competitive advantage in light of the COVID-19 pandemic. This is a preliminary study of the sustainable competitive advantage literature that includes the concept of strategic leadership as a knowledge management processes enabler for achieving a sustainable competitive advantage. Until now, there has not been any work like it in the literature, save in the qualitative style.

Keywords: sustainable competitive advantage; strategic leadership capabilities; knowledge management processes; theoretical framework; COVID-19; human capital; social capital; resource-based view; knowledge-based view; knowledge creation theory

\section{Introduction}

The COVID-19 pandemic has had enormous global economic, political, and societal ramifications. This unforeseeable tragedy of historic proportions has affected not just business revenues but also consumer behavior and demand. The most important concern is simply to survive in an uncertain internal and external environment that influences the global productivity and competitiveness potential [1]. In today's business strategy management research, the subject of what constitutes a sustainable competitive advantage (SCA) is a hot topic, and the knowledge-based view (KBV) of SCA's source has garnered a lot of attention. 
Indeed, as global rivalry, environmental turmoil, and the knowledge economy rise, knowledge is viewed as a strategic asset that allows businesses to gain a competitive advantage [2]. The knowledge economy's expanding relevance is altering corporate landscapes. The new economy is centered on understanding how individuals learn, relearn, and unlearn in order to create economic value [3-6]. As a result of the necessity for public and private enterprises within service industry providers such as educational institutions, telecommunication firms, banks, and tourism services to make more reasonable and effective use of their knowledge, knowledge management has risen to prominence. Knowledge management can provide a competitive advantage and aid in the development of knowledge-intensive economies. Furthermore, knowledge management is a vital component of the digital transformation's success [7]. Knowledge management can be especially important during the COVID-19 outbreak; hence, proper knowledge management implementation can help enterprises survive the pandemic while also promoting good performance [1]. The transformation of managers' ideas into strategic assets such as organizational knowledge is part of the knowledge economy [8]. Knowledge has long been regarded as a strategic resource that must be managed in order to improve an organization's competitive performance [9]. As a result, one would expect businesses to be successful if they leverage their knowledge assets methodically [10]. Knowledge management is becoming more popular in today's business world as a long-term source of competitive advantage [11]. If the rising knowledge economy needs knowledge-based firms to employ knowledge management as their primary source of competitiveness, then the knowledge management processes (KMPs) capabilities that make up the dynamic fabric of these organizations are the most important factors in establishing competitiveness [12]. The primary goal of knowledge management processes is to make it easier for individuals and teams to share information. One of the primary problems for such programs is ensuring that these flows are efficiently facilitated so that maximal knowledge transfer occurs [13]. To face this issue, knowledge management methods must be properly utilized, which cannot be done without the support of organizational knowledge leadership [12].

Strategic leadership [14] is one technique to manage organizational knowledge. Knowledge management, when backed up by strategic leadership, can provide tactical instruments for achieving sustainable competitive advantage [15]. Employees" "human capital" and "social capital" are regarded as the most essential assets of a knowledge-based firm by the strategic leadership. These variables can also be viewed as knowledge leadership, as they create conditions that permit and support effective knowledge management $[16,17]$. Thus, leadership is critical in the management of knowledge inside businesses $[18,19]$. Knowledge management projects can fail if senior managers provide insufficient or incompetent assistance [20,21]. Traditionally, leadership research has not focused on leadership as a knowledge management enabler [22]. Recent research, however, has stressed the relevance of leaders in knowledge management $[15,17,23-26]$.

Therefore, this research paper aims to develop an integrated conceptual and theoretical framework that connects strategic leadership capabilities, knowledge management processes, and a sustainable competitive advantage. In this paper, knowledge management processes play a mediating role in the relationship between strategic leadership capabilities and a sustainable competitive advantage.

\section{Background of COVID-19}

Particularly, more than one year ago (January 2020), COVID-19 presented humanity with new and unprecedented challenges. Suddenly, normality was not what it used to be. The routines of people, organizations, and societies were severely affected. For organizations, this situation requires reflection on both the strategy and the actions that should be performed. Therefore, the current crisis requires new ways of applying knowledge strategies and new ways of dealing with dynamic capabilities [27]. In this context, some authors assumed that COVID-19 happened in the scope of a globalized knowledge economy driven by services $[27,28]$. In this economy and society, macro and micro actors 
exist; also, the basic elements are technology, people, and processes [29]. Therefore, the COVID-19 crisis is first and foremost a crisis of knowledge [27]. This knowledge within organizations needs to be managed to meet environmental changes and new challenges in the time of COVID-19. Knowledge management is therefore defined as the process by which people, organizations, and societies manage their knowledge resources. More precisely, it is linked with the management of intangible resources-knowledge is one of the most important of those resources [27]. The knowledge management processes are based on the capabilities of all members of the organization to add value to the basic business processes through the creation, communication, codification, and coordination of both explicit and tacit knowledge stores [30].

Additionally, the coronavirus epidemic has mostly affected the global economy and all kinds of businesses. Economic conditions, trading conditions, and organizational needs have all been changed by the COVID-19 epidemic. Businesses require new strategies, scenarios, and leadership styles to overcome uncertainty in the business environment that the COVID-19 epidemic has brought. The number of new leadership theories that are characterized is increasing day by day. This increase is depending on continuous changes in environmental conditions. A variable of fluctuations in the business environment increases the need for new leadership styles that can effectively respond to the needs of the change in business processes and cope with uncertainty. One of the new leadership styles that can develop strategies successfully in a rapidly changing environment is strategic leadership [31]. Based on the resource-based view (RBV) [32-36] and dynamic capabilitybased approach [37], strategic leadership is the ability of the leader to be prepared for every possible future challenge, having the capability and the power to manage the organization's critical resources to achieve SCA in the marketplace [38]. In the same view, strategic leadership is the leader's capabilities to configure and leverage human and social capital to create value for the organization [39].

According to the RBV [32-36], the dynamic capability-based approach [37], and the competence-based perspective $[36,40,41]$, the development method in competitive strategy works through the development and integration of intangible assets and capabilities in internal and external environments $[36,40,41]$. To sum up, human capital, social capital, skills, and knowledge are recognized as organizational resources, while strategic leadership and knowledge management processes are capabilities. The strength of some resources to create a sustainable competitive advantage is dependent upon interactions or combinations with capabilities. Consequently, through interactions or combinations of strategic leadership capabilities and knowledge management processes capabilities with organizational resources, the organization can stay ahead of its competitors and continue to attain a sustainable competitive advantage and earn superior retunes during and after the COVID-19 situation.

\section{Sustainable Competitive Advantage}

The SCA can be regarded as having a superior position or condition over a competitor over a long period of time by reacting to the world's endless changes [42]. The term "competitive advantage" is more widely employed. In terms of strategic management, competitive advantage is a concept that continues to be a prominent research field [43]. "A firm such as... that earns superior financial returns within its industry (or its strategic group) over the long run is said to possess a competitive edge over its rivals", according to Ghemawat [44] (p. 49). In competitive and slow-growth markets, strategic senior managers' primary pre-work is to gain a competitive edge. This characterizes many businesses today, and scholars and practitioners have been concerned about the sources of competitive advantage over the past two decades [32,36,45-50]. As a result, it is commonly understood that most organizations, regardless of sector, should acknowledge that gaining competitive advantages is the most difficult issue facing businesses in the twenty-first century.

As global competition becomes more intense, the question of how to maintain a competitive advantage or develop SCA is becoming more prominent. According to Barney [32], 
a business has a competitive advantage if it is implementing a value-creating strategy that is not being adopted by any present or potential competitors at the same time. When other companies are unable to duplicate the benefits of this strategy, they can verify that the company has SCA. There are two sorts of competitive advantage, according to Barney and Hesterly [51]: temporary and sustainable. They claim that competitive advantage usually leads to significant profits, but that these earnings attract competitors, and that competition, in most situations, limits the length of competitive advantage. As a result, the most significant competitive advantage is only temporary. Some competitive advantages, on the other hand, can be sustained if competitors are unable to duplicate the source of advantage or if no competitor can think of a superior product.

As a framework for the capacity of business resources to generate SCA, Barney [32] presented four indicators: value, rarity, costly to imitate, and non-substitutable VRIN. Barney Barney [46] later improved the concept from VRIN to VRIO by adding the question: "Is a company organized to use these resources?" Barney [46] defined SCA as an organization's resources and capabilities that are critically heterogeneous and immobile based on four traits or empirical indicators of value (V), rarity (R), imperfectly imitability (I), and organization $(\mathrm{O})$ to capture and utilize the value of them as SCA sources. According to Barney and Clark [52], the VRIO framework is a modified version of the RBV theoretical framework, which Rothaermel [53] (p. 91) adopted. According to Barney [46] and Barney and Clark (2007) [52], SCA is defined as an organization's resources, capabilities, competencies, and core competencies that are critically heterogeneous and immobile based on four attributes of empirical indicators of value (V), rarity (R), imperfectly imitability (I), and organization $(\mathrm{O})$ to capture and exploit a resource.

\section{Process of Sustainable Competitive Advantage}

The SCA is a dynamic process that fulfils current competitive needs without risking the organization's potential to meet future competitive needs. Subjects, media, objectives, and continuous change are four factors that make up the basic idea of the SCA process $[9,14]$. SCA's subjects are resources. Resources are units of analysis among a company's most basic aspects, and they are natural objects to analyse because they represent input to the company's business value process [54-56]. In other words, resources are the inputs to the value chain of a business [57]. Additionally, resources are designated as SCA sources if they are valuable, unique, difficult to duplicate, and well-organized [52].

The media is the second component of the SCA process. It is a subprocess that transforms the first element's resources and talents as subjects into capabilities, competences, and core competencies. The ability of a company to exploit its resources is referred to as its capability. This is made up of a set of business procedures and routines that control how a company's resources interact [57]. There are three sorts of skills, according to prior empirical studies: particular or individual skills, processes, and organizational capacities [58,59]. According to contemporary studies, distinguished capabilities can be classified as either dynamic or operational [56]. Dynamic capabilities are those that build, integrate, and modify operational capabilities [37,60]. Operational capabilities are all the procedures that are normally involved when conducting an activity such as manufacturing. Several experts, including Savory [61] and Javidan [57], believe that dynamic capabilities are more important to an organization than operational capabilities. Furthermore, according to Javidan [57], a capability has less organizational value and complexity than competence. Competencies are a type of cross-functional capability integration and coordination. Ljungquist [62] defined competences both conceptually and experimentally as advances made by individuals and teams. Individuals and groups of individuals are usually considered to have intrinsic competencies, meaning that the competence idea comprises a cumulative hierarchy. The cumulative hierarchy concept is visible in various lines of research involving the connected notions, which are based on competences, capabilities, and dynamic capabilities, respectively, according to Savory [61]. Scholars often differentiate between distinctive and core distinctive competencies [63]. Distinctive competence is a 
difficult-to-copy strength within a firm that may be exploited to generate long-term profits, whereas core distinctive competence is the primary driver of the aspirations system.

One of the most well-known strategic management concepts is a core competence. Prahalad and Hamel [36] coined the term "core competency" to describe skills inside varied organizations from a competence-based approach [36,40,41]. They described core competency as an organization's collective learning, particularly how to coordinate multiple making abilities and integrate multiple flow technologies. Core competence is a collection of abilities and procedures that enables a company to deliver a competitive edge to its consumers. Employees typically identify core skills by scanning and assessing three aspects known as linked concepts: company-critical resources, capabilities, and competencies [36]. Many studies on competitive advantage have emphasized core competencies as the primary source of advantage. Core competencies are a set of competences, abilities, and areas of knowledge that are shared across strategic business units and are the result of the integration and harmonization of strategic business units' competencies across the organization [57]. Ljungquist [62] concurred with Prahalad and Hamel [36] in using three criteria to identify a core competency from a competence. To begin, a core skill must make a meaningful contribution to providing customers with advantages from a product/service. Second, a core competency should be competitively distinct and difficult to copy by competitors. Third, a core competence should be able to access a wide range of markets and should be capable of continual improvement and development.

The objective is the third component of the SCA process. It is a subprocess to be better or different from competitors or to be impossible to duplicate. Although possessing varied and immobile resources, skills, competences, and core competencies is important for creating a competitive advantage, it is not enough if the company wants to maintain it. According to the RBV, the resources, capabilities, competences, and core competencies that meet all of the VRIO criteria maintain competitive advantages [9].

Updating is the fourth step in the SCA process. The idea is to look at the SCA from a strategic standpoint and evaluate it as a dynamic process. SCA, according to Pearce and Robinson [64] and Czinkota and Kotabe [65], comprises long-term strategies that differentiate a business from its competitors, such as price strategy, strategy-structure fit, communication strategy, or cross-functional cooperation. If organizations truly desire to have SCA, Hitt, Ireland, et al. [66] argued that they should be able to resist the upheaval environment and generate a new competitive advantage in the process. Jiajia [67] described SCA as a continuous process. Specifically, businesses should gain a new competitive edge before the current one deteriorates. Enterprises establish a continuous corrugated track by building competitive advantage as a continuum in mutual relationships.

\section{Strategic Leadership Capabilities}

According to the RBV, strategic leaders must focus on important resources, capabilities, and/or competences, as these are potential variables that lead to SCA and long-term success. Some researchers have endorsed this viewpoint, such as Hitt and Ireland [39], who believe that strategic leadership is about having key resources, such as connections and partnerships with various organizations (social capital), as well as forming outstanding teams (human capital). Nevertheless, Crossan, Vera, and Nanjad [68] and Hitt, Ireland, et al. [66] feel that strategic leadership is a leader's ability to predict, foresee, and cause the organization to remain in its successful state, as well as versatility to encourage strategic change that is sensitive to the company's current circumstances. Furthermore, Boal [69] described strategic leadership as a process that develops, concentrates, and empowers an organization's people and social resources and competencies in order to achieve the actual time it takes to acquire opportunities and threats. Furthermore, Hirschi and Jones [38] define strategic leadership as the leader's readiness for any future event as well as his or her competence to manage the organization's critical resources in order to attain SCA. Hitt and Ireland [39], Ireland and Hitt [70], and Mahdi and Almsafir [14] described strategic leadership as a leader's ability to foresee, imagine, preserve flexibility, think strategically, 
and collaborate with others to configure, develop, and use human and social resources to create value.

Effective strategic leadership capabilities (SLCs) are required in the new competitive landscape envisaged in the twenty-first century, according to the strategic literature assessment [66,70,71]. Exploring and sustaining unique core competences, creating human capital, and developing social capital were all combined into one action by Hitt, Ireland, et al. [66] as efficiently managing the firm's resource portfolio. The ability to successfully manage the organization's portfolio of resources is perhaps the most critical duty for strategic leaders. Strategic leaders organize resources into capabilities, structure the company to exploit the capabilities, and develop and implement a strategy to leverage those resources to gain a competitive advantage [72]. Strategic leaders must, in particular, utilize and sustain the organization's fundamental strengths, as well as build and retain the company's human and social capital [66]. Managing human and social capital is at the heart of strategic leadership [58]. Furthermore, McCallum and O'Connell [73] noted that human capital and social capital are not mutually exclusive. This is reflected in the fact that some leadership skills can be viewed as both human and social capital. As a result, the SLCs focus on the development of human and social capital. According to Hitt and Ireland [39] and Mahdi and Almsafir [14], creating human and social capital was chosen as the SLC for the purposes of the study.

\subsection{Developing Human Capital}

The fundamental component of intellectual capital is emphasizing human capital as a component of intellectual capital $[74,75]$. The term "human capital" refers to a company's complete workforce's "knowledge and skills" [66] (p. 388). Employees' human capital contributes to the development of the organization's overall intellectual capital, according to the human capital theory [76]. Employees' knowledge, skills, capabilities, commitment, know-how, ideas, and health are all examples of important resources that bring economic value to firms [76,77]. "The competences, tacit experiences, and general knowledge-base of employees in an organization are represented by human capital" [78] (p. 55). Human capital, according to Bart [79], is an organization's personnel cumulative knowledge, education, attitudes, experiences, and certain identifiable abilities. Ballout [80] described HC as a theoretical foundation for understanding an individual's approach to professional achievement. Human capital, on the other hand, refers to processes involving training, education, and other professional initiatives to improve an employee's knowledge, skills, abilities, values, and social assets, resulting in the employee's satisfaction and performance and eventually the organization's performance [81]. Individual knowledge was defined by Au, Altman, and Roussel [74] as human capital inside an organization. Human capital has established itself in current academia and commercial practice as a means of explaining economic success and individual well-being at both the national and organizational levels [82]. Human capital may be the most significant resource in today's knowledge-based economy for all types of enterprises, products, and services, large and small, new and established. Hitt, Haynes, and Serpa [12], Hitt and Ireland [39], and Hitt, Ireland, et al. [66] all emphasized the value of investing in human capital development.

Human capital investments would be high, according to the human capital theory, if employees benefited greatly from the developed human capital $[77,83]$. Human capital benefits also include a high individual return on investment, an increase in return, the potential to become a future leader, the opportunity to work on high-profile projects, and a rise in position and authority $[39,77,78,84,85]$. These are employee-perceived advantages based on the quantity of human capital production perceived by employees [76]. Bontis and Serenko [78], on the other side, explained human capital benefits in terms of the human capital value and human capital effectiveness, respectively, in terms of human capital return on investment and return factor. Furthermore, as the world becomes more globalized, human capital development is becoming more important, and it is one of the most important ways to enter the international realm [86]. Human capital development 
could be viewed in this light as a firm's investment in improving the competence of its personnel to gain a competitive advantage [87].

\subsection{Developing Social Capital}

Social capital, like human capital, is a component of intellectual capital and unavoidably contributes to human capital development [76]. That is inherent in the acuteness of individuals' social perceptions and the structure of their social interactions, according to Balkundi and Kilduff [88]. Furthermore, Prusak and Cohen [89] defined social capital as the active relationships between individuals, where trust, shared understanding, shared values, and behaviours bind members of human networks, allowing cooperative action. "Social capital is the goodwill available to individuals or groups", according to Adler and Kwon [90] (p. 23). The form and content of the actor's social relationships are its sources. Its impacts are a result of the information, influence, and solidarity that it provides to the actor. According to Nahapiet and Ghoshal [91], social capital is the sum of real and potential resources embedded in, available through, and generated from a social unit's network of interactions. It was discovered that social capital includes both presented knowledge about what is already established with the environment and knowledge collected by different parties during knowledge exchanges. Social capital, on the other hand, refers to internal and external ties that help businesses complete tasks and produce value for consumers and shareholders. A company's social capital is a valuable asset. Strategic leaders must reconcile social capital within their units and organizations, as well as social capital in external environments $[39,89,90]$.

Effective strategic leaders develop social capital, which leads to favourable company outcomes [73]. As a result, the strategic leader's ability to continually create and effectively integrate the organization's external social with internal social capital has an impact on the organization's performance. To build external social capital, leaders must first identify and create relationships with the organization's partners [92]. Leadership would assist people to learn how to relate to others, coordinate their activities, make commitments, and develop extended social networks, according to Edmonstone [93]. Strategic leadership ability, according to Hartley, Martin, and Benington [94], is defined as the ability to understand contexts and situations, build alliances and alignment, balance the interests of major stakeholders, and take on strategic directions and scanning in the construction and maintenance of social networks.

Organizations can develop social capital, according to Nahapiet and Ghoshal [91] and Prusak and Cohen [89], by building trust through transparency and authentic leadership, providing time and space for people to connect and have personal conversations, and establishing recognition and reward systems that support and reinforce collaboration. Leadership development can help to increase social capital by not only improving the performance of individual leaders but also through fostering relationships, coordinating actions, and extending and strengthening the social network [95]. Creating a shared understanding between strategic leaders and personnel within the business, as well as between strategic leaders and people outside the organization, is one of the ways that leadership can help to generate social capital [96]. Raelin and Coghlan [97] also claim that creating shared knowledge can help the organization's institutional memory. In essence, "performing leadership" entails the establishment of shared understanding. It allows the spread of information within the organization and the emergence of a single sense of "who we are". Shared understanding can also help to reinforce new behaviours and keep them going over time.

The essence of the social capital theory, according to Ellinger, Baş, Ellinger, Wang, and Bachrach [98], is that interpersonal relationships are the key to success and that fostering stronger connections within social networks by creating environments that promote trust, relationship, and goodwill yields positive outcomes. Furthermore, strategic leaders are in a unique position to improve access to knowledge, learning methodologies, and networks for their staff. Strategic leaders are critical in developing, structuring, and reinforcing 
information shared across the enterprise. Strategic leaders promote intra- and extraorganizational dialogue, encourage the growth of views and assumptions, generate new ideas, and initiate collective action to improve cognition. Individuals are encouraged to contribute new ideas/schema to old problems as well as uncover new challenges to which known or knowable shared schema can be applied through interacting with a wide range of networks, both inside and outside the firm's borders [99].

\section{Knowledge Management Processes}

Knowledge management (KM) is widely recognized among academics as a crossfunctional and multidimensional discipline [15]. Researchers and academics have defined KM in a variety of ways. Singh [19] viewed KM as a process that fosters information sharing and establishes learning as a continuous activity inside an organization from a systematic process perspective. More than that, KM is a collection of well-defined processes or methods for locating critical information across various KM operations [100]. Furthermore, knowledge management (KM) is a systematic way to managing organizational knowledge and activities, such as developing, structuring, organizing, retrieving, sharing, and assessing an organization's knowledge assets [101]. KM, on the other hand, is the strategic application of collective organization knowledge and know-how to increase profits and market share [102]. KM is also about managing and building a corporate culture that supports and encourages the sharing, appropriate utilization, and development of knowledge that permits a strategic competitive advantage for the company [103]. Albers and Brewer [104] agreed, describing KM as an innovation process that includes the invention, acquisition, incorporation, allocation, and application of knowledge to improve an organization's operational efficiency and competitive advantage. Furthermore, KM provides the appropriate information to the appropriate group at the appropriate time. Furthermore, from the perspective of an intangible asset, $\mathrm{KM}$ is the concept of a deliberate design of processes, tools, and structures to increase, renew, share, or improve the use of knowledge represented in any of the three elements of intellectual capital (structural, human, and capital) [105]. KM is a process of developing knowledge to transform an organization into a learning organization [98] from the standpoint of organizational learning. Finally, in terms of KM definitions, the current study underlines that KM is a holistic concept that encompasses all of the issues raised by these definitions. According to this viewpoint, $\mathrm{KM}$ is an intellectual absorb for the information age. As a result, the literature supports Drucker's [106] conclusion that there is no such thing as knowledge management in the same way that there is knowledge management in the management of those who know.

The importance of KMPs in contemporary organizations has been highlighted in the academic literature [107], with some authors claiming that an organization's ability to generate knowledge is critical [30,108]. KM, according to Bollinger and Smith [109], is both a goal and a process. They reasoned that knowledge management is focused on sharing information for the benefit of the organization as a consequence and aim. Knowledge management practices are more about sharing, cooperation, and making the best possible use of a strategic resource than they are about control. KMPs are socially enacted activities that support individual and group knowledge and engagement, according to academics $[110,111]$. These activities differ according to the available knowledge resources (human and social capital). As a result, the company should decide which of these activities it wants to support and then adopt appropriate organizational elements and technology to make that possible [112]. The KMPs are built on everyone in the organization's ability to bring value to core business processes by creating, communicating, codifying, and coordinating both explicit and tacit knowledge repositories [102]. Nonaka and Takeuchi [102] proposed that the flow of information passes through socialization, externalization, combination, and eventually internalization. Starting with the raw experience, understanding, categorizing, and lastly creating personal mental models that transcend the experience are all part of it. 
The KMPs are dynamic, interdependent, and intertwined systems. Individuals and teams can be involved in various aspects of these knowledge processes at any time and in any part of a company. Furthermore, knowledge management is a dynamic, cyclical process that requires employees to engage with information continuously, acquire new knowledge, apply it to improve decisions, generate new information and knowledge in the process, apply that new knowledge to new situations, and so on. The KMPs are founded on three principles. People must first have information; second, they must be willing to put that knowledge to use; and third, they must have the capacity and intelligence to recognize when to put that knowledge to use [113]. KMPs may also help to maintain a competitive advantage, according to some research [9]. Organizations must continuously develop new knowledge, allow its exchange within them, and apply it to create products or services to obtain a competitive advantage through KMPs [108,109].

According to Mertins, Heisig, and Vorbeck [114], the Fraunhofer IPK Berlin model of KMPs was used for this study: "Knowledge management describes all methods, instruments, and tools in a holistic approach that contribute to the promotion of the core knowledge processes - to generate knowledge, store knowledge, distribute knowledge, and apply knowledge supported by the identification of a problem" (p. 3). The phrase "information distribution process" has been changed and adapted in this study with the term "knowledge sharing process", which Al-Alawi [115] emphasizes as an important procedure. The success of knowledge management techniques is influenced in great part by the top and mid-level management support, according to this paradigm. As a result, leadership is a crucial aspect of achieving success. Each manager is responsible for promoting and personifying information exchange. In the following part, we will go over these procedures.

\subsection{Knowledge Identification}

The initial sub-process of knowledge selection is knowledge identification. This sub-process establishes the requirement for information and how to find the appropriate knowledge [9]. The demand for information must be determined before it can be developed or disseminated [116]. The identification of knowledge, according to Heisig and Vorbeck [117], is an essential foundation for every knowledge management initiative. The goal is to determine what corporate information exists, who the knowledge carriers are, and where this knowledge is housed. Suppliers, customers, and research institutions can all be sources of information, both within and externally. The value of knowledge identification in an organization is determined by the organization's objectives, infrastructure, and culture, according to Davenport and Prusak [118]. Knowledge identification also refers to recognizing and realizing the organization's knowledge demands [119]. After identifying organizational knowledge, a requirements analysis can be undertaken to bridge the gap between current knowledge and the knowledge required to define an organization's skills and competitiveness, as well as to assure its ability to survive and adapt [120].

\subsection{Knowledge Goals Formulation}

Practical knowledge management starts initially with the development of clear goals. This is vital for the selection of suitable methods and the subsequent control and evaluation of performance [9]. Heisig and Vorbeck [113] divided the knowledge goals formulation into short-term (clarity), medium-term (processes improvement, easier decision, and predictions), and long-term goals (success and market leadership, customer orientation, and satisfaction). Furthermore, knowledge goals also point the way for KMPs. They determine which capabilities should be built on which level. Normative knowledge goals deal with the creation of a knowledge-sensitive corporate culture, in which sharing and development of know-how create the preconditions for effective knowledge management. Strategic knowledge goals define organizational core capabilities and describe the future knowledge needs of the organization. They determine the desirable competence portfolio for the future and are therefore an extension of the organization's traditional planning processes. 
Operational knowledge goals make sure that normative and strategic knowledge goals will be translated into action $[116,117]$.

\subsection{Knowledge Generating}

The acquisition and creation of knowledge are referred to as knowledge generation [109]. Internal procedures for creating, generating, developing, building, and constructing knowledge are referred to as knowledge acquisition. The process of gaining fresh and helpful insights and ideas is referred to by these phrases [118]. Knowledge creation refers to an organization's ability to generate new and beneficial ideas and solutions for a variety of activities, including goods, technological processes, and managerial practices $[119,120]$. Knowledge generation is regarded as one of the key KMPs in most prior and new publications [9]. In comparison to other KMPs, it is the most important because it is via this approach that organizations or individuals develop knowledge that is shared with or utilized by others [121,122]. Knowledge-generating is defined by Mertins et al. (2001) as measures and instruments that stimulate the generation and acquisition of external knowledge, as well as approaches to elicit tacit knowledge. Awad and Ghaziri [123] and Heisig and Vorbeck [113] both demonstrated how knowledge is generated mostly through teamwork and knowledge translation experience. In addition, Huber [124] pointed out that knowledge creation can and should occur in an unregulated manner. This depicts the options of obtaining or generating the needed knowledge once the need for knowledge has been acknowledged and it cannot be discovered internally. Two types of knowledge can appear while developing knowledge, according to Nonaka and Takeuchi's SECI (socialization, externalization, combination, and internalization) process model [102]. They are tacit and explicit knowledge, which are embedded in the goods, services, and labor processes of a business once they are created. Knowledge generating and process execution were linked by Bontis and Serenko [70], who viewed knowledge producing to be a major outcome of human capital management methods.

\subsection{Knowledge Storage}

Knowledge storage activities include categorizing knowledge into various categories, sending knowledge in time activities, and storing knowledge in the organization's database activities [121]. Knowledge storage, according to Vorbeck and Finke [122], is a structured and systematic competence. The storing knowledge potential for expert systems was discussed by Heisig and Vorbeck [117]. Many businesses have historically overlooked the impact of organizational memory. As a result, outsourcing or a high rate of worker turnover almost always results in the loss of organizational knowledge [9]. However, to access and recover information in the future, it must be continuously stored on the organization's various data carriers, equipped with the appropriate indexing mechanisms, and updated [116]. Furthermore, knowledge must be updated regularly because knowledge in the knowledge society becomes obsolete quickly [116].

\subsection{Knowledge Sharing}

Knowledge sharing refers to the degree of intra-organizational collaboration and involves both vertical and horizontal communication of ideas, papers, news, "lessons learned", know-how, and other pertinent information [78]. After existing knowledge has been recognized or new knowledge has been developed, knowledge sharing is completed [9]. Because one of the primary objectives of knowledge management research and practice is to promote the flow of knowledge among organization members $[123,124]$ to add value and create opportunities for competitive advantage $[115,125]$, this sub-process is regarded as the core process of knowledge management. Knowledge sharing, according to Bartol and Srivastava [126], is described as social contact among employees in a department or organization as they share organizationally relevant information, ideas, suggestions, and expertise. Employees formally and informally share tacit and explicit information [127]. Sun and Hao [116] identified three sub-processes of knowledge sharing 
performance. Documentation, conversion, and exhibition are all examples of knowledge representation. Second, knowledge distribution aids in the dissemination of information that must be made available across the organization. Finally, knowledge application is aided by knowledge use.

\subsection{Knowledge Application}

The purpose of knowledge is the application of the relevant knowledge that is available after it has been distributed. Only the application of knowledge allows for new individual and communal learning processes. New information is developed as a result [9]. As a result, knowledge's essential operations can be thought of as a closed-loop [117]. By integrating the available knowledge papers, knowledge users can combine the knowledge and apply it to actual practice at this point. This technique provides information on how to adapt the knowledge management strategy [128]. Knowledge application, according to the researchers, is defined as "the practice of acquired knowledge from other members or divisions in a meaningful way in specific organizational divisions" [129].

\section{Underlying Theories}

The resource-based view is regarded as one of the most prominent ideas in management research history, particularly in terms of strategic management deployment [33,34,130-132]. The RBV of the firm is a stream of research that also encompasses three closely related but different schools of thought: a resource-based view of the firm, a dynamic capabilitybased view of the firm, and a competence-based view of the firm. Some scholars consider the three views to be one school of thought that shares the same underlying theoretical structure [133]. The RBV's basic concept is to use the company's resources, particularly internal sources [134], and core competencies to develop SCA, which leads to improved performance. The RBV stresses an organization's distinct assets and competencies that make the difference in gaining a competitive advantage. As a result, management efforts should be directed at gathering [32,33], developing, and exploiting these strategic resources in order to maintain a competitive advantage [135]. According to Barney [32], not all business resources have the ability to provide sustainable competitive advantages. To have this potential, the firm resource must possess four characteristics that Barney defines as an organization's strategic competencies for sustaining competitive advantage: value, rarity, imperfection, and non-substitutability.

Organizational resources are all tangible and intangible assets controlled and owned by an organization, such as capabilities, organizational processes, organizational characteristics, information, knowledge, and physical structures. They allow it to execute efficiency and effectiveness methods that lead to SCA and increased performance $[32,33,136]$. The capability to undertake a task or activity that requires complex patterns of coordination and collaboration between human capital and resources is known as capability $[54,132]$. Strategic assets are these resources and competencies that must be included in the end-products or services that provide value to customers.

There has been a lot of research into different approaches to conceptualizing the RBV in empirical investigations. Newbert [137] divided past RBV empirical research theoretical methods into four categories: resource heterogeneity, organizational approach, conceptual level, and dynamic capabilities. When a firm controls a valuable, rare, inimitable, and non-substitutable resource, capability, or core competence, the resource heterogeneity approach claims that it will affect the firm's competitive advantage or performance. The organizing approach discusses the conditions that allow for effective resource and capability exploitation at the company level. Scholars are using the conceptual level approach to see if the characteristics of a resource, such as value, rarity, and inimitability, can effectively explain performance [32]. Finally, the dynamic capabilities approach focuses on individual resource-level processes that influence competitive advantage or performance, with a given resource interacting with a specific dynamic capability as an independent variable. 
Scholars, on the other hand, have been more prone to emphasize the capabilities of firms rather than their processes in the most recent growing trend associated with the RBV. As a result, concepts such as combinative capabilities [138], capabilities [138], architectural competency [139], and dynamic capabilities [60] have been employed by various academics. The definitions of these concepts, on the other hand, all refer to business activities that employ specific resources, integrate them, reconfigure them, and release new competitive advantage resources [59]. Therefore, the goal of this research is to create a model that incorporates capabilities and processes to aid the SCA process of transforming resources into capabilities, competences, and core competencies. The competitive advantage, according to the RBV, resides in better organizational resources, skills, and/or competencies. Human capital, social capital, skills, and knowledge are all regarded as increasingly important organizational resources in this context $[54,66,140]$. Because the effectiveness of some resources is contingent on their interactions or combinations with other resources or talents, no single resource, real or intangible, emerges as the most crucial for sustaining competitive advantage and improving organizational performance. An organization may stay ahead of its competition and continue to achieve superior returns by developing the combination of its tangible and intangible assets [37]. As a result, the firm may stay ahead of its competition and continue to achieve superior returns by combining SLCs and KMPs skills with organizational resources. The RBV, in conclusion, is an excellent beginning point for SCA since it teaches how to identify possible SCA resources and capabilities within organizations from a strategic standpoint.

Researchers established the knowledge-based view (KBV), which is an extension of the RBV view that conceptualizes organizations as diverse knowledge-bearing entities [141], based on the RBV [32,33] and dynamic capabilities approach [37]. According to Kogut and Zander [138] (p. 284), the knowledge-based view argues that knowledge is a crucial reason for the existence of businesses: "what firms do better than markets is the sharing and transfer of the knowledge of individuals and groups inside an organization". Polanyi [142] came up with the KBV (p. 4). He divided knowledge into two categories: explicit knowledge, or codified knowledge, which refers to knowledge that can be formally transmitted and articulated to others, and tacit knowledge, which is a personal knowledge that is difficult to formalize and communicate and is embedded in people that they cannot articulate. When Polanyi [142] (p. 4) famously stated, "we know more than we can say that we know", he was referring to tacit knowledge. Knowledge is the most strategically important resource in the company, according to the KBV $[50,138]$. With the rise of the strategic management approach in the management literature, knowledge as a vital resource has continued to attract more attention, where it is viewed as a corporate asset, a competitive advantage, and a change manager [143]. As a result, Nonaka's [144] knowledge generation theory is employed to support the KBV, which is one of the underpinning ideas in this study.

Knowledge is formed, according to information creation theory, by interaction and conversion of tacit and explicit knowledge. Employees can convert knowledge in four different ways: tacit knowledge to tacit knowledge via socialization, tacit knowledge to explicit knowledge externalization, explicit knowledge to explicit knowledge via combination, and explicit knowledge to tacit knowledge via internalization (SECI). Different types of knowledge conversion follow one another in a spiralling process of knowledge development [144]. This approach also emphasizes knowledge generation at the organizational and inter-organizational levels $[30,145]$ through dialectical processes [145] among individuals and groups. Knowledge creation theory provides a framework for individual knowledge generation as well as organizational knowledge accumulation. The cornerstone of organizational renewal and SCA [36] is the creation of new knowledge. Companies must constantly absorb existing knowledge, produce new knowledge, and pursue practical wisdom to attain and retain competitiveness and sustainable growth [2]. 


\section{Strategic Leadership Capabilities and Sustainable Competitive Advantage}

Hitt et al. [71] explored, modelled, and constructed important strategic leadership components, which Hagen, Hassan, and Amin [146] investigated empirically. According to the findings, American chief executive officers (CEOs) recognized the need to integrate the important components of the suggested model of corporate strategic leadership. Hitt and Ireland [39] investigated the relevance of both types of human and social capital to leaders and how they might be managed to create value for the unit and the enterprise in a theoretical study. Both are important factors in obtaining a competitive edge from the RBV. Ireland and Hitt [70] underlined the importance of strategic leadership in achieving and maintaining strategic competitiveness in the same environment. The firm's strategic leadership practices can become a source of competitive advantage if the strategic leadership components are executed correctly. Furthermore, strategic leadership in a company that can grow its capabilities will be able to keep its competitive advantage. Several firms have attempted to maintain a competitive advantage by utilizing resources and capabilities, according to the RBV $[34,36]$. By managing the organization's portfolio of resources (human capital and social capital), strategic leadership enables the conversion of resources or skills into genuine capability or competency [39]. This is accomplished by converting those resources or talents into capabilities and reorganizing the organization to take advantage of those capabilities and, furthermore, developing those resources to gain a competitive edge and ensure long-term viability $[15,66]$. Furthermore, boosting human and social capital adds value to the company and aids in the development of SCA [38,39]. In their study, the authors of [14] discovered that SLCs have a strong positive impact on SCA. As a result of what was found in the literature review, the study proposed that:

$P_{1}$. Strategic leadership capabilities have a significant relationship with a sustainable competitive advantage.

\section{Strategic Leadership Capabilities and Knowledge Management Processes}

In the processing of knowledge, leadership plays an important role [147]. Strategic leaders, according to Boal and Schultz [99], are critical components of the adjustment process of a complex adaptive system. This is because they are in a unique position to improve workers' access to knowledge and encourage individuals to contribute new ideas, learning methodologies, and networks to solve challenges. The art of knowledge management methods is significantly and negatively connected with both directive and supportive leadership styles, according to Singh [19]. He also shows that counselling and delegating leadership styles are both favourably and strongly associated with knowledge management. Furthermore, only the delegating mode of leadership behaviours was found to be predictive of knowledge production and management for competitive advantage. According to Sayyadi [6], transformational leadership has a favourable impact on knowledge management. The link between SLCs and KMPs, on the other hand, has been largely ignored in the study. As a result, based on the findings of the literature research, it is proposed that:

$P_{2}$. Strategic leadership capabilities have a significant relationship with knowledge management processes.

\section{Knowledge Management Processes and Sustainable Competitive Advantage}

Integrated KMPs for product knowledge, according to Leitch and Rosen [148], give an organization a competitive advantage. Bou-Llusar and Segarra-Ciprés [149] looked at the consequences of strategic knowledge and knowledge transfer mechanisms for competitive advantage. They looked at one of the most important issues in a KBV, defining the source of competitive advantage: knowledge vs. KMPs of acquisition, transfer, and generation. KMPs and SCA have a substantial association, according to Mahdi, Nassar, and Almsafir [9]. As a result, the study recommended that:

$P_{3}$. Knowledge management processes have a significant relationship with a sustainable competitive advantage. 


\section{Strategic Leadership Capabilities, Knowledge Management Processes, and Sustainable Competitive Advantage}

Leadership is characterized as the capability to influence a group toward achieving a vision or set of objectives [150]. Strategic leaders are needed in today's changing world to challenge the status quo, generate future visions, and motivate the organization. According to a review of leadership literature, information management and knowledge management are crucial leadership roles. Information and knowledge management, as well as expertise held by leaders, are vital for achieving a competitive advantage, according to several approaches to leadership research [151]. Furthermore, Hitt and Ireland [39] concurred and said from the RBV $[32,33]$ that strategic leadership aspires to maximize the organization's people and social capital. Furthermore, Hirschi and Jones [38]; Hitt, Haynes, et al. [12]; and Hitt and Ireland [39] all concurred in their investigations that the diverse methods for the study of strategic leadership suggest that strategic leaders' KM is vital for SCA. As a result, the study recommended that:

$P_{4}$. Knowledge management processes mediate the relationships between strategic leadership capabilities and sustainable competitive advantage.

\section{Method of Study}

The model approach has been used to build a theoretical framework that predicts the relationships between the concepts [152]. A conceptual model describes an entity and identifies issues that should be considered [152-154]. The potential goals and applications in a model paper are explaining and predicting relationships between constructs, identifying novel connections between constructs, developing theoretical propositions that introduce new constructs and/or relationships between constructs, and explaining why a sequence of events leads to an outcome. The starting point in research design considerations is phenomenon or theory/concept, the choice of domain theories through the literature that addresses key elements of the phenomenon/concept to be explained, and the choice of method theory that enables the explanation of relationships between the studied variables [152]. The current paper builds on theories and augments the literature and ideas presented in the conceptual and theoretical model of the study to investigate the relationship between strategic leadership capabilities, knowledge management processes, and sustainable competitive advantage with the primary objective of formulating a set of detailed propositions.

\section{The Proposed Research Framework}

Several firms have attempted to maintain a competitive advantage by utilizing resources and capabilities based on the resource-based view. According to the resource-based view [32-36], knowledge-based view [138,142], and knowledge creation theory [30,145], most strategic leaders believe that investing in human capital and social capital to develop tacit and explicit knowledge may improve their organizations' sustainable competitive advantage. Most studies, however, have not looked into how businesses might use knowledge assets to achieve a sustainable competitive advantage through strategic leadership capabilities and knowledge management processes. Furthermore, earlier similar theories did not devote enough attention to how to turn resources or abilities into tactical capability, competency, or core competence. Because there will be no sustainable competitive advantage if there is no such conversion. Rather, they looked at strategic leadership, knowledge management processes, and sustainable competitive advantage separately.

In the field of strategic leadership and knowledge management, there are few research attempts, notably in corporate organizations. Some scholars have undertaken theoretical analyses of the link between strategic leadership and sustainable competitive advantage based on the resource-based view $[12,39,70,155]$. Using grounded theory, several of them performed theoretical investigations on higher education leadership roles in knowledge processing [147] and the function of senior executives in knowledge management [151]. 
Others [156-159] have undertaken empirical research that focused on the link between KM and sustainable competitive advantage.

Neither scholars nor practitioners, on the other hand, have looked into the idea of an integrated model. As a result, no empirical research on the integration of strategic leadership capabilities, knowledge management processes, and sustainable competitive advantage in business organizations has been conducted so far. This study proposes an integrative model of strategic leadership capabilities, knowledge management processes, and sustainable competitive advantage processes in organizations in order to fill this research gap.

This paper's study framework aims to offer an integrative view of strategic leadership capabilities, knowledge management processes, and sustainable competitive advantage, as well as provide strategic recommendations for businesses. The study looked at past empirical investigations to see if strategic leadership capabilities had an effect on sustainable competitive advantage and if knowledge management processes had a mediating effect on the association between strategic leadership capabilities and sustainable competitive advantage. It becomes easy to comprehend how strategic leadership capabilities develop information to support knowledge management processes and further extract the value of those knowledge management processes to sustainable competitive advantage by presenting knowledge management processes as a mediating variable.

Relevant theories such as the resource-based view [32-36], knowledge-based view [138,142], and knowledge production theory [30,145] provide an integrative perspective of strategic leadership capabilities, knowledge management processes, and sustainable competitive advantage variables. RBV is the theory that underpins all of these hypotheses. The idea of strategic leadership has been developed from the perspective of human and social capital development $[39,66,70]$. On a tactical level, the notion of knowledge management processes has been examined from the strategic perspective of organizational skills in organizing and disseminating critical knowledge [160]. The theoretical framework was continually refined after the literature survey was completed, which makes this study unique. The study's models were discovered through the literature review. The conceptual and theoretical study frameworks in this paper are based on the strategic leadership model, which focuses on capabilities $[39,66,70]$, the knowledge management model, which focuses on processes capabilities [114,144,160-162], and the sustainable competitive advantage model, which focuses on processes $[9,32,33,36,37,40,41]$.

Due to the nature of the research aims, which are to explore the influence of strategic leadership capabilities and knowledge management processes capabilities in the sustainable competitive advantage process, the capabilities-based approach [37] is used in the study. It should also be highlighted that relatively few empirical studies on strategic leadership have taken a capabilities-based approach. The study framework for this paper is built on two primary strategic leadership capabilities, four sustainable competitive advantage constructs, and six knowledge management process capabilities, as described in the literature review and to fill the research gap left by prior studies.

\subsection{Conceptual Frameworks}

Three key conceptual frameworks for the study emerged from the literature review. Figure 1 depicts the first conceptual framework, which illustrates that two primary aspects influence an organization's ability to construct sustainable competitive advantage: strategic leadership capabilities and knowledge management processes. These criteria impact the organization's ability to develop a sustainable competitive advantage at various levels. Strategic leadership capabilities are the independent variable. Strategic leadership capabilities involve creating both human and social capital, according to multiple recent studies by Burt [163]; Hitt, Haynes et al. [12]; Hitt and Ireland [39]; Hitt, Ireland, et al. [66]; Hitt, Keats, and Yucel [164]; and Ireland and Hitt [70]. Human capital refers to a company's complete workforce's "knowledge and skills" [66] (p. 388). The sum of the existing and potential resources contained within, available through, and generated from an individual's or social 
unit's network of relationships is referred to as social capital [91] (p. 243). Information, technology, know-how, and skills are all examples of knowledge, which are seen as a significant resource and potential source of capabilities and competencies for innovations and new product creation. Integrating these resources better than competitors creates value and sustainability. It encompasses explicit knowledge, which may be officially expressed as numbers, words, software, and so on, as well as tacit knowledge, which includes intuitions, hunches, and insight $[118,142]$. As markers in creating sustainable competitive advantage, strategic leadership generates and retains an organization's people and social capital. Organizations can grow human capital and social capital value, improve KMPs via explicit and tacit knowledge value, and eventually boost their sustainable competitive advantage by implementing effective strategic leadership capabilities.

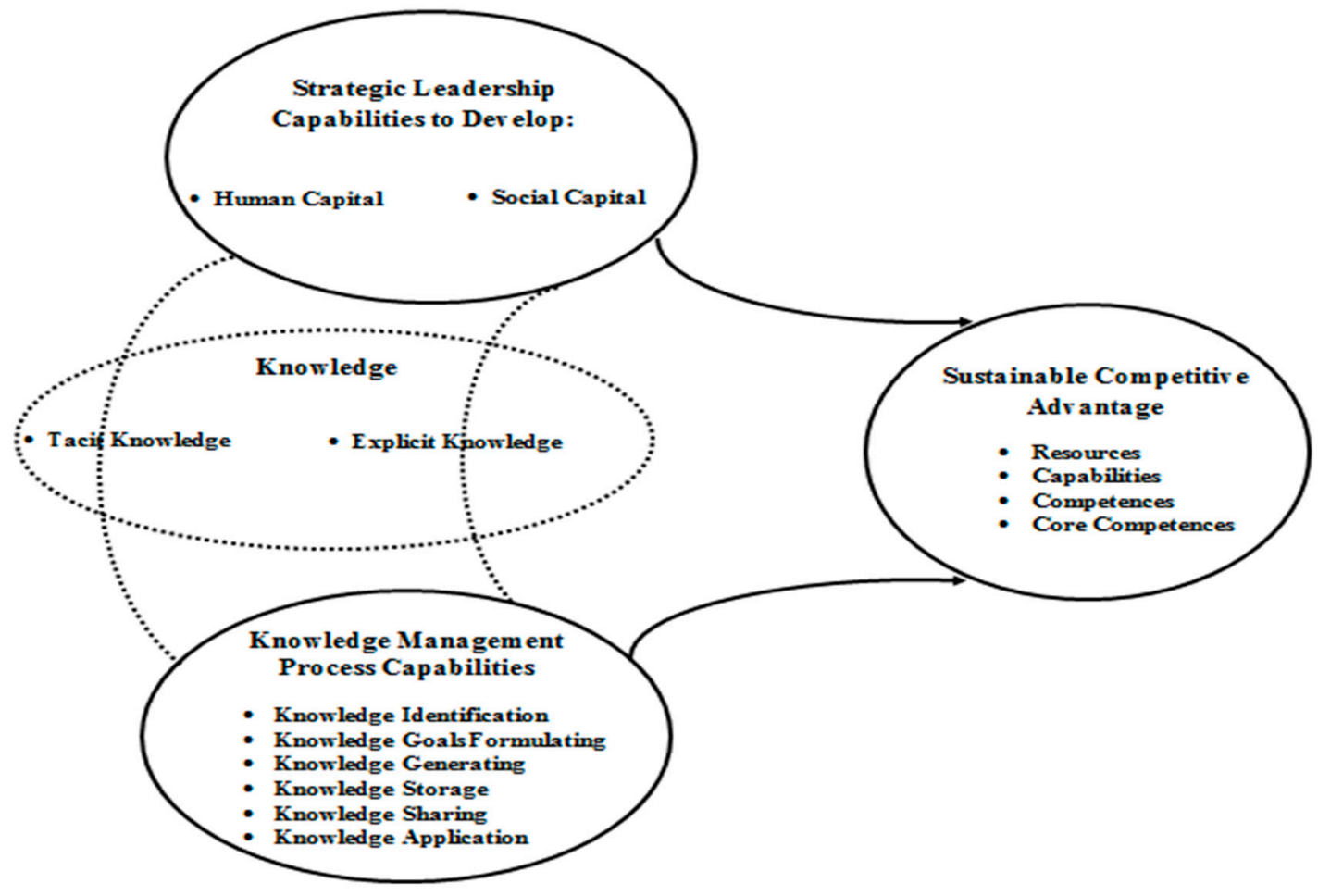

Figure 1. Conceptual framework.

The sustainable competitive advantage is the dependent variable. The four aspects that make up the basic principle of the sustainable competitive advantage process are subject, media, objective, and continuous change. According to the resource-based view [32,33], the subjects are resources. The transition of subjects into media, or the transformation of heterogeneous and immobile resources into capabilities, competencies, and core competencies, is what the media is all about. The goals are to evaluate resources, skills, competencies, and core competencies in terms of how valuable, scarce, and expensive to copy they are, as well as how well-organized the organization is to capture value VRIO [46,52]. The sustainable competitive advantage will be reviewed as a dynamic process as part of the update element.

The knowledge management processes are demonstrated by the mediator variable. The literature review justified and explained the knowledge management processes as a mediator theoretically. Knowledge management processes are the production, communication, codification, and coordination of both explicit and tacit knowledge stores based on the capacity of all people of the organization to add value to essential business operations, according to knowledge creation theory [30]. Tacit knowledge refers to knowledge that is difficult to express in formal language, stems from personal experience, perceptions, and values, and is context-dependent [165]. It is regarded as the construction organization's 
most strategically vital resource, as well as the only renewable and sustainable base for its activities and competitiveness [166]. The knowledge that may be transmitted in formal, systematic languages is referred to as explicit knowledge [167]. Tacit and explicit knowledge are complementary, which indicates that both types of knowledge are important in the formation of new knowledge. Without tacit insight, explicit knowledge quickly loses its meaning. Information is formed by the interaction of tacit and explicit knowledge, rather than by either tacit or explicit knowledge alone [161].

To process and manage tacit and explicit knowledge, knowledge management processes employ the capabilities of knowledge identification, knowledge goals formulation, knowledge generation, knowledge storage, knowledge sharing, and knowledge application. Strategic leadership capabilities generate tacit and explicit knowledge by growing human capital and social capital in order to add value. This extra value is reflected in the organization's sustainable competitive advantage.

In this study, the resource-based view is used to describe the process of combining resources and capabilities. Strategic leadership represents the organization's strategic capabilities. Human and social capitals are both strategic assets. Developing human capital and social capital are conceptually associated and linked to tacit and explicit knowledge $[12,39,70,73,76,90,91,168,169]$. They build the channels that connect strategic leadership capabilities and knowledge management processes capabilities. Knowledge management processes are tactical capabilities within an organization. The strategic leadership capabilities and knowledge management processes capabilities translate strategic resources into capabilities, competences, and core competencies based on the resource-based view's distinctive traits of being valuable, scarce, costly to replicate, and organized [33,46,52]. As a result, the impact of strategic leadership capabilities on sustainable competitive advantage is assessed in conjunction with the organization's resources, skills, competences, and core competencies in growing human capital and social capital. Furthermore, the impact of strategic leadership capabilities on knowledge management processes capacities is examined in conjunction with the development of human and social capital, as well as knowledge identification, knowledge goal formulation, knowledge generation, knowledge storage, knowledge sharing, and knowledge application.

The impact of knowledge management processes capabilities in sustainable competitive advantage is also taken into account when integrating knowledge identification, knowledge goals formulation, knowledge generation, knowledge storage, knowledge sharing, and knowledge application with the organization's resources, capabilities, competencies, and core competencies [9]. Because strategic knowledge integration is the focus of the knowledge-based view [170], this work used strategic leadership capabilities along with knowledge management processes capabilities to develop and add knowledge value to an organization's sustainable competitive advantage.

As a result, there is evidence that strategic leadership capabilities can interact with knowledge management processes' capabilities to alter sustainable competitive advantage. However, this basic conceptual framework must be expanded in order to handle the study's complexity through conceptual framework development. Another specific conceptual framework can be developed from the conceptual framework, as shown in Figure 2. 


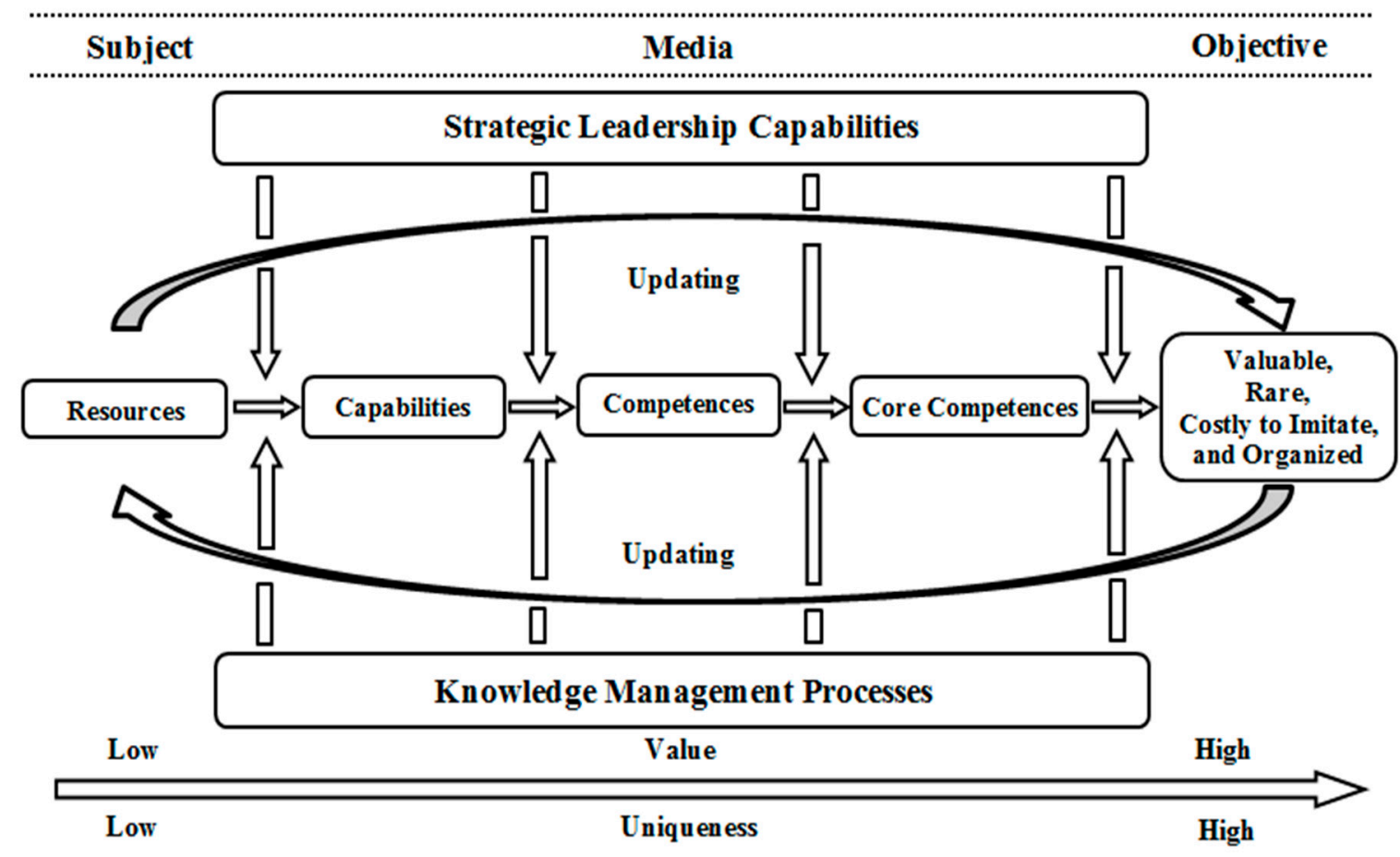

Figure 2. Specific conceptual framework.

\subsection{Theoretical Framework}

The study advised that an adequate theoretical framework be constructed to reflect the setting in which the paper was performed, based on the conceptual frameworks, and to be operationalized and extended on them. A theoretical framework, according to Sekaran and Bougie [171], specifies how variables, factors, or concepts in a model are related to one another. The theoretical framework, according to Sekaran [172], conceptualizes how one theorizes the relationships among numerous components that have been identified as essential to the problem. A theoretical framework can be compared to a road map or itinerary. It is critical to consider the appropriate theory behind the knowledge base of the phenomenon to be researched at the start of every research investigation. If this framework is to be empirically relevant, it must have a clear practical outcome. Designing a theoretical framework is a conceptual and experiential process [173]. As a result, Figure 3 depicts the theoretical framework, with strategic leadership capabilities as the exogenous variable. In $S=$ structural equation modelling (SEM), the sustainable competitive advantage is the endogenous variable. Knowledge management processes classified as mediators serve a dual purpose. The mediator variable is supposed to moderate the link between strategic leadership capabilities and sustainable competitive advantage. Finally, this report will propose relationships between study variables. 


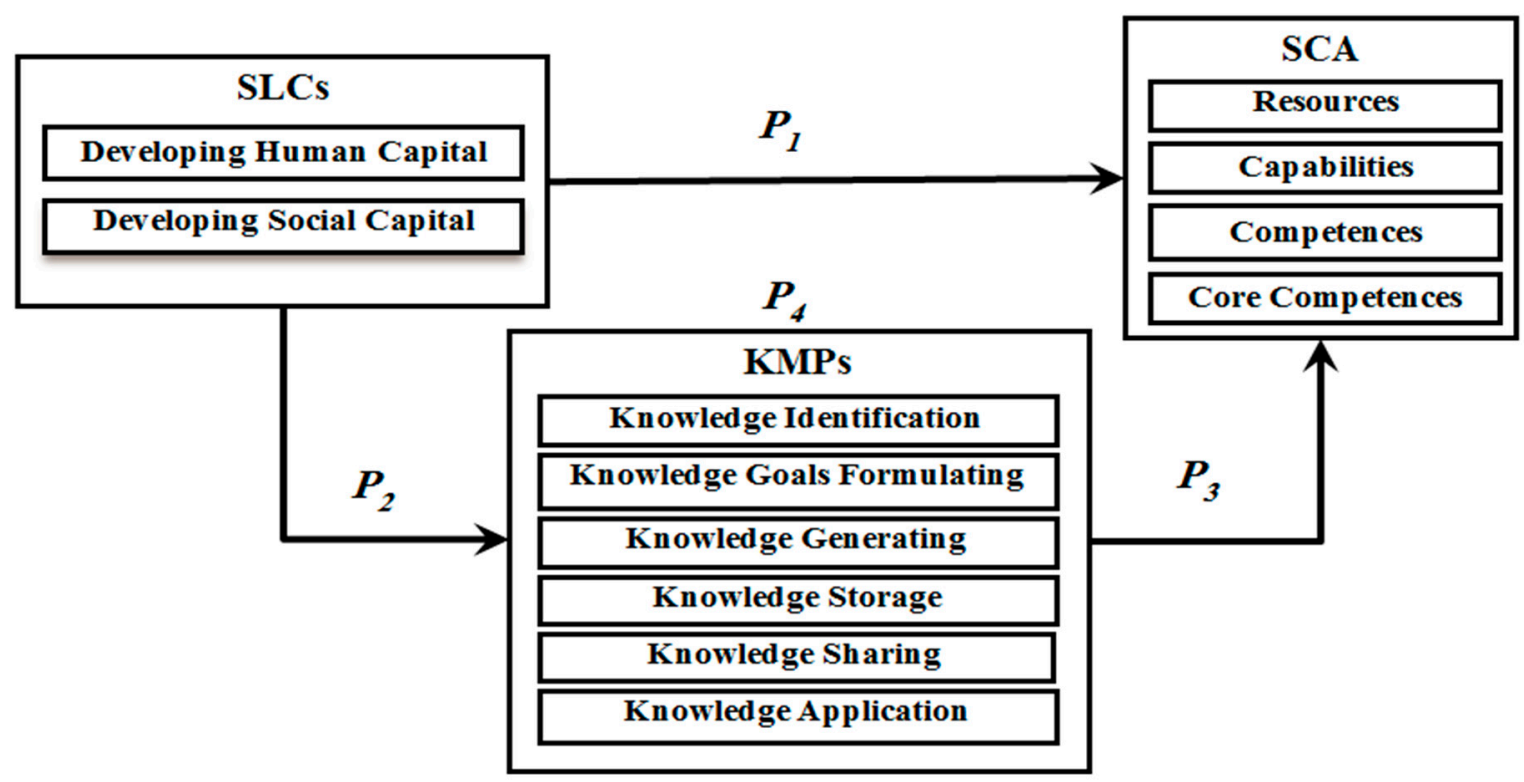

Figure 3. The theoretical framework (pre-analysis).

\section{Conclusions}

In line with the main strategic thoughts provided by the resource-based view, the knowledge-based view, and the knowledge creation theory, companies have realized that their sustainable competitive advantage results both from the possession of resources that are hard to transfer and accumulate, inimitable, not substitutable, tacit in nature, synergistic, and not consumable because of their use and the ways of combining and developing them. Consequently, a growing interest in the processes of management of knowledge resources has been experimented with in the last decades. Several theoretical models and approaches aimed at explaining how organizational knowledge is created, transferred, and crystallized have been produced. Often, the proposed models and approaches have used different terminology to denote similar knowledge processes [174]. Therefore, this study attempted to develop an integrated business model of strategic leadership capabilities, knowledge management processes, and sustainable competitive advantage. The main goal was to explain the link between strategic leadership capabilities and sustainable competitive advantage, as well as the mediating role played by the knowledge management processes in this interaction. The proposed business model enhances underlying theories such as the resource-based view [32-36], knowledge-based view [138,142], and knowledge creation theory $[30,145]$. Further, the theoretical framework built in this study consists of the main dimensions of strategic leadership capabilities, a complete cycle of knowledge management processes, and a sustainable competitive advantage process as compared to previously developed frameworks $[9,14,39,114,175]$. Furthermore, the present model describes benchmarks and improves previous business models by altering or reinforcing how they are positioned concerning the interdependent elements of business models. The theoretical model suggested the importance of strategic leadership capabilities and knowledge management processes to achieve a sustainable competitive advantage for the service industry companies. More broadly, the outcomes reflect the growing discussion over strategic leadership capabilities' role in supporting knowledge management processes and the formation of sustainable competitive advantage for public and private enterprises within service industry providers such as educational institutions, telecommunication firms, banks, and tourism.

The proposed model can assist strategic leaders in improving knowledge management processes through explicit and tacit knowledge value in order to achieve and increase sustainable competitive advantage. The postulated link between strategic leadership capabilities, knowledge management processes, and sustainable competitive advantage 
received substantial support from the study's developed theoretical framework. Strategic leadership is also linked to human and social capital, according to this study. Based on the fundamental theories in this study, such as the resource-based view [32-36], knowledgebased view [138,142], and knowledge creation theory [30,145], it is also used to improve knowledge management processes and a sustainable competitive advantage. This research also demonstrates that in order to improve a sustainable competitive advantage, a combination of organizational resources and competencies must be established, deployed, and protected in the resource-based view. New knowledge is a vital strategic resource [50], according to the resource-based view [32,33] and knowledge-based view [138]. The acquisition of new knowledge is one example of gaining a competitive advantage through learning processes achieved through the combination of strategic leadership qualities and knowledge management processes. The subjects of sustainable competitive advantage are RBV-based resources [32,33,52]. Resources are also referred to as "tangible resources" and "intangible resources" by others. Both of these resources can be considered part of the resource-based view and knowledge-based view's captured value. Capability, competency, and core competence are the media of sustainable competitive advantage. The crucial question is how to turn sustainable competitive advantage issues into media, which can also be regarded as value creation from a value chain perspective [176]. According to the resource-based view [32,33], dynamic capability-based approach [37], and competencybased perspective $[36,40,41]$, subjects are transformed into media by changing resources into capabilities, competencies, and core competencies. The active resources, dynamic capabilities, robust competences, and core competencies of organizations are assessed to determine the objectives for achieving a sustainable competitive advantage. In terms of VRIO [46,52], this assessment is based on the distinctive attributes of resources, capabilities, competencies, and core competency. To adapt to the fast-changing world, the sustainable competitive advantage's subject-media-objective process must be modified. As a result, these four aspects form the foundation of the sustainable competitive advantage process, and none of them are optional. This study's theoretical research approach also adds to the body of knowledge in the fields of strategic leadership, knowledge management, and sustainable competitive advantage. Finally, the study concludes that strategic leadership and knowledge management process competencies are strategic assets that must be combined in order to achieve a sustainable competitive advantage.

This research paper offers several theoretical implications that enrich the body of knowledge in the cross-cultural literature. It also provides a practical implication for practitioners in their workplaces. In terms of the theoretical implication, this work made a substantial contribution to the existing literature on strategic leadership capabilities, knowledge management processes, and their effect upon sustainable competitive advantage. In addition, it addressed the remedy for the gaps in the present literature on a comprehensive understanding of the relationship between strategic leadership capabilities, knowledge management processes, and the sustainable competitive advantage. Especially, previous studies consider knowledge management processes as a mediating variable $[76,177,178]$, but these constructs were not tested in terms of their relationship with strategic leadership capabilities and sustainable competitive advantage. The paper provided strong support to the resource-based view, knowledge-based view, and knowledge creation theory by suggesting that a sustainable competitive advantage could be enhanced through a combination of organizational capabilities. The concept of strategic leadership capabilities applied in this study focuses on value creation and extraction. The objective of strategic leadership is to create and leverage intellectual assets and improve organizational value-creating capabilities from a strategic perspective. Strategic leadership, as critical organizational capabilities, can be captured as strategic capabilities to exploit, maintain, develop, and retain the strategic assets as an organization's human and social capital. It can also integrate both the internal tacit knowledge and external explicit knowledge necessary to support the knowledge management processes and provide the required knowledge values. Additionally, knowledge management was discussed from a process capabilities perspective. 
It is considered an organization's capability to transform its tacit knowledge and explicit knowledge into a valuable form. Knowledge is created through interactions between tacit and explicit knowledge. Human and social capital are conceptually related and connected to tacit and explicit knowledge. Thus, knowledge constructs the transition channels from strategic leadership to knowledge management. Therefore, there exists evidence that strategic leadership capabilities can work with knowledge management processes to impact a sustainable competitive advantage. This study significantly contributed to assessing the sustainable competitive advantage from the four elements used to construct the basic idea of the sustainable competitive advantage, none of which are dispensable. These elements are the subject, media, objective, and update process. Based on the resource-based view, this paper focuses mostly on the review of the sustainable competitive advantage as a dynamic process in terms of changing resources into capabilities, competencies, and core competencies. In terms of practical implications, this study provides practitioners and company owners with information on how to use strategic leadership capabilities and knowledge management processes to attain a sustainable competitive advantage in service industry enterprises to combat the COVID-19 pandemic. This gives the service industry enterprises the ability to stay ahead of present or potential competition and ensure service industry market leadership and long-term survival. This research paper also provides visions of how the strategic leaders in the service industry enterprises deal with the competitive environment to tackle the difficulties of the digital and knowledge revolution in light of the COVID-19 pandemic. It has made a large contribution to explaining and comprehending the need for strategic leadership in managing human and social capital while dealing with employees and clients from various cultural backgrounds, particularly in terms of leveraging employees' knowledge to develop internally developed core competencies that are valuable, rare, inimitable, and organized to achieve sustainable competitiveness [46,52]. The outcomes of the research paper also practically can contribute to being a stepping stone in formulating robust strategies for developing standardized best capabilities for strategic leadership and knowledge management processes in service industry enterprises in an international context to achieve sustainable competitive advantage. The current model is conceptually and empirically applicable by practitioners in contexts extending beyond mere service companies but also to manufacturing companies. Finally, the present study recommends that future research be conducted to investigate empirically.

Author Contributions: Conceptualization, O.R.M. and I.A.N.; literature review; O.R.M. and I.A.N.; methodology, O.R.M. and I.A.N.; writing—original draft preparation, O.R.M. and I.A.N.; writingreview and editing, O.R.M. and I.A.N. All authors have read and agreed to the published version of the manuscript.

Funding: This research received no external funding.

Institutional Review Board Statement: Not applicable.

Informed Consent Statement: Not applicable.

Data Availability Statement: Not applicable.

Conflicts of Interest: The authors declare no conflict of interest.

\section{References}

1. Hsieh, H.C.; Nguyen, X.H.; Wang, T.C.; Lee, J.Y. Prediction of knowledge management for success of franchise hospitality in a post-pandemic economy. Sustainability 2020, 12, 8755. [CrossRef]

2. Yu, C.; Zhang, Z.; Lin, C.; Wu, Y.J. Knowledge creation process and sustainable competitive advantage: The role of technological innovation capabilities. Sustainability 2017, 9, 2280. [CrossRef]

3. Zhao, Y.; Lu, Y.; Wang, X. Organizational unlearning and organizational relearning: A dynamic process of knowledge management. J. Knowl. Manag. 2013, 17, 902-912. [CrossRef]

4. Kwon, K.; Cho, D. How transactive memory systems relate to organizational innovation: The mediating role of developmental leadership. J. Knowl. Manag. 2016, 20, 1025-1044. [CrossRef]

5. Villasalero, M. Intra-network knowledge roles and division performance in multi-business firms. J. Knowl. Manag. 2014, 18, 1165-1183. [CrossRef] 
6. Sayyadi, M. How effective leadership of knowledge management impacts organizational performance. Bus. Inf. Rev. 2019, 36, 30-38. [CrossRef]

7. Alvarenga, A.; Matos, F.; Godina, R.; Matias, J.C.O. Digital transformation and knowledge management in the public sector. Sustainability 2020, 12, 5824. [CrossRef]

8. McFarlane, D.A. Effectively Managing The 21st Century Knowledge Worker. J. Knowl. Manag. Pract. 2008, 9, 3-7.

9. Mahdi, O.R.; Nassar, I.A.; Almsafir, M.K. Knowledge management processes and sustainable competitive advantage: An empirical examination in private universities. J. Bus. Res. 2019, 94, 320-334. [CrossRef]

10. Bolisani, E.; Bratianu, C. Knowledge strategy planning: An integrated approach to manage uncertainty, turbulence, and dynamics. J. Knowl. Manag. 2017, 21, 233-253. [CrossRef]

11. Kassaneh, T.C.; Bolisani, E.; Cegarra-Navarro, J.G. Knowledge management practices for sustainable supply chain management: A challenge for business education. Sustainability 2021, 13, 2956. [CrossRef]

12. Hitt, M.A.; Haynes, K.T.; Serpa, O. Strategic leadership for the 21st century. Bus. Horiz. 2010, 53, 313-328. [CrossRef]

13. Sandhawalia, B.S.; Dalcher, D. Developing knowledge management capabilities: A structured approach. J. Knowl. Manag. 2011, 15, 313-328. [CrossRef]

14. Mahdi, O.R.; Almsafir, M.K. The role of strategic leadership in building sustainable ccompetitive advantage in the academic environment. Procedia Soc. Behav. Sci. 2014, 129, 289-296. [CrossRef]

15. Lee, H.; Choi, B. Knowledge management enablers, processes, and organizational performance: An integrative view and empirical examination. J. Manag. InformtUion Syst. 2003, 55, 179-228. [CrossRef]

16. Calabrò, A.; Torchia, M.; Jimenez, D.G.; Kraus, S. The role of human capital on family firm innovativeness: The strategic leadership role of family board members. Int. Entrep. Manag. J. 2021, 17, 261-287. [CrossRef]

17. Holsapple, C.W.; Singh, M. Knowledge chain model: Activities for competitiveness. Expert Syst. Appl. 2001, 20, 77-98. [CrossRef]

18. Donate, M.J.; Guadamillas, F. Organizational factors to support knowledge management and innovation. J. Knowl. Manag. 2011, 15, 890-914. [CrossRef]

19. Singh, S.K. Role of leadership in knowledge management: A study. J. Knowl. Manag. 2008, 12, 3-15. [CrossRef]

20. Davenport, T.H.; De Long, D.W.; Beers, M.C. Successful knowledge management projects. Sloan Manag. Rev. $1998,93,43-57$.

21. Xue, Y.; Bradley, J.; Liang, H. Team climate, empowering leadership, and knowledge sharing. J. Knowl. Manag. 2011, 15, 299-312. [CrossRef]

22. Lakshman, C. Organizational knowledge leadership: An empirical examination of knowledge. Organ. Dev. J. 2009, 30, 338-364. [CrossRef]

23. Yeh, Y.-J.; Lai, S.-Q.; Ho, C.-T. Knowledge management enablers: A case study. Ind. Manag. Data Syst. 2006, 106, 793-810. [CrossRef]

24. Chu, K.W. Leading knowledge management in a secondary school. J. Knowl. Manag. 2016, 20, 1104-1147. [CrossRef]

25. Gamo-Sanchez, A.L.; Cegarra-Navarro, J.G. Factors that influence the success of a KM-program in a small-sized airport. J. Knowl. Manag. 2015, 19, 593-610. [CrossRef]

26. Millar, C.C.J.M.; Lockett, M.; Mahon, J.F. Guest editorial: Knowledge intensive organisations: On the frontiers of knowledge management. J. Knowl. Manag. 2016, 20, 845-857. [CrossRef]

27. Tomé, E.; Gromova, E. Development of emergent knowledge strategies and new dynamic capabilities for business education in a time of crisis. Sustainability 2021, 13, 4518. [CrossRef]

28. Tomé, E. Human resource development in the knowledge based and services driven economy. J. Eur. Ind. Train. 2011, 35, 524-539. [CrossRef]

29. Edwards, J. A process view of knowledge management:it ain't want you do, it's the way that you do it. Electron. J. Knowl. Manag. 2011, 9, 297-306.

30. Nonaka, I.; Takeuchi, H. The Knowledge-Creating Company: How Japanese Companies Create the Dynamics of Innovation; Oxford University Press: New York, NY, USA, 1995.

31. Studies, T.; Sciences, S. Strategic Leadership: Best Practical Leadership Style to Business Strategies in the Period of Covid-19 Epidemic. Turkish Stud. Sci. 2020, 15, 1946-1955. [CrossRef]

32. Barney, J. Firm Resources and sustained competitive advantage. J. Manag. 1991, 17, 99-120. [CrossRef]

33. Wernerfelt, B. A resource-based view of the firm. Strateg. Manag. J. 1984, 5, 171-180. [CrossRef]

34. Barney, J.B. Strategic factor markets expectations, luck, and business strategy. Manag. Sci. 1986, 32, 1231-1241. [CrossRef]

35. Haanes, K.; Fjeldstad, Ø. Linking intangible resources and competition. Eur. Manag. J. 2000, 18, 52-62. [CrossRef]

36. Prahalad, C.; Hamel, G. The core competence of the corporation. Harv. Bus. Rev. 1990, 68, 79-91.

37. Teece, D.J.; Pisano, G.; Shuen, A. Dynamic capabilities and strategic management. Strateg. Manag. J. 1997, 18, 509-533. [CrossRef]

38. Hirschi, G.; Jones, M. Affects of strategic leadership on business success-A cross-cultural analysis from a resource based view. MIBES Trans. 2009, 3, 1-18. [CrossRef]

39. Hitt, M.A.; Ireland, R.D. The essence of strategic leadership: Managing human and social capital. J. Leadersh. Organ. Stud. 2002, 9, 3-14. [CrossRef]

40. Sanchez, R.; Heene, A. Reinventing strategic management: New theory and practice for competence-based competition. Eur. Manag. J. 1997, 15, 303-317. [CrossRef] 
41. Sanchez, R. Understanding competence-based management-Identifying and managing five modes of competence. J. Bus. Res. 2004, 57, 518-532. [CrossRef]

42. Webster. Webster's New Twentieth Century Dictionary of the English Language Unabridged, 1st ed.; The Publisher's Guild; World Publishing: New York, NY, USA, 1961.

43. Njuguna, J. Strategic Positioning for Sustainable Competitive Advantage: An Organizational Learning Approach. KCA J. Bus. Manag. 2009, 2, 32-43. [CrossRef]

44. Ghemawat, P. Strategy and the Business Landscape: Core Concepts; Prentice Hall: New York, NY, USA, 2001.

45. Cockburn, I.M.; Henderson, R.M.; Stern, S. Untangling the origins of competitive advantage. Strateg. Manag. J. 2000, 21, 1123-1145. [CrossRef]

46. Barney, J.B. Looking inside for competitive advantage. Acad. Manag. Perspect. 1995, 9, 49-61. [CrossRef]

47. Barney, J.B. Gaining and Sustaining Competitive Advantage, 3rd ed.; Pearson Prentice-Hall: Hoboken, NJ, USA, 2007.

48. Porter, M.E.; Kramer, M.R. Strategy and Society Strategy and Society. Harv. Bus. Rev. 2006, 84, 78-92.

49. Peteraf, M. The cornerstones of competitive advantage: A resource-based view. Strateg. Manag. J. 1993, 14, 179-191. [CrossRef]

50. Grant, R.M. Prospering as in integration environments: Organizational capability knowledge. Organ. Sci. 1996, 7, 375-387. [CrossRef]

51. Barney, J.; Hesterly, W. Strategic Management and Competitive Advantage: Concepts and Cases, 3rd ed.; Prentice Hall: Hoboken, NJ, USA, 2009.

52. Barney, J.; Clark, D. Resource-Based Theory: Creating and Sustaining Competitive Advantage, 1st ed.; OUP Oxford: New York, NY, USA, 2007.

53. Rothaermel, F. Strategic Management: Concepts and Cases, 1st ed.; McGraw-Hill Irwin: New York, NY, USA, 2013.

54. Grant, R.M. The Resource-Based Theory of Competitive Advantage: Implications for Strategy Formulation. Calif. Manag. Rev. 1991, 33, 114-135. [CrossRef]

55. Eisenhardt, K.M.; Santos, F.M. Knowledge-based view: A new theory of strategy? In Handbook of Strategy and Management; Pettigrew, A., Thomas, H., Whittington, R., Eds.; Sage: London, UK, 2000; pp. 139-164.

56. Helfat, C.E.; Peteraf, M.A. The dynamic resource-based view: Capability lifecycles. Strateg. Manag. J. 2003, 24, 997-1010. [CrossRef]

57. Javidan, M. Core competence: What does it mean in practice? Long Range Plann. 1998, 31, 60-71. [CrossRef]

58. Galbreath, J. Which resources matter the most to firm success? An exploratory study of resource-based theory. Technovation 2005, 25, 979-987. [CrossRef]

59. Tuan, N.P.; Yoshi, T. Organisational capabilities, competitive advantage and performance in supporting industries in Vietnam. Asian Acad. Manag. J. 2010, 15, 1-21.

60. Eisenhardt, K.; Martin, J. Dynamic capabilities: What are they? Strateg. Manag. J. 2000, 21, 1105-1121. [CrossRef]

61. Savory, C. Translating knowledge to build technological competence. Manag. Decis. 2006, 44, 1052-1075. [CrossRef]

62. Ljungquist, U. Specification of core competence and associated components: A proposed model and a case illustration. Eur. Bus. Rev. 2008, 20, 73-90. [CrossRef]

63. Eden, C.; Ackermann, F. Mapping distinctive competencies: A systemic approach. J. Oper. Res. Soc. 2000, 51, 12-20. [CrossRef]

64. Pearce, J.A.; Robinson, R.B. Formulation, Implementation, and Control of Competitive Strategy, 9th ed.; McGraw-Hill International: New York, NY, USA, 1995.

65. Czinkota, M.R.; Kotabe, M. Entering the japanese market: A reassessment of foreign firms' entry and distribution strategies. Ind. Mark. Manag. 2000, 29, 483-491. [CrossRef]

66. Hitt, M.A.; Ireland, R.D.; Hoskisson, R.E. Strategic Management: Concepts and Cases Competitiveness and Globalization, 8th ed.; South-Western College Pub: Cincinnati, OH, USA, 2010.

67. Jiajia, W. Study on the Key Influence Factors in the Evolution from Operational Optimization to Sustainable Competitive Advantage. Master's Thesis, Northwestern Polytechnic University, San Francisco, CA, USA, 2007.

68. Crossan, M.; Vera, D.; Nanjad, L. Transcendent leadership: Strategic leadership in dynamic environments. Leadersh. Q. 2008, 19, 569-581. [CrossRef]

69. Boal, K.B. Strategic leadership. In Encyclopedia of Leadership, (Vol. 3); Goethals, G.R., Sorenson, G.J., Burns, J.M.G., Eds.; SAGE Publications: Thousand Oak, CA, USA, 2004; pp. 1497-1504.

70. Ireland, R.D.; Hitt, M.A. Achieving and maintaining strategic competitiveness in the 21 st century: The role of strategic leadership. Management 2005, 19, 63-77. [CrossRef]

71. Hitt, I.; Ireland, R.; Hoskisson, R.E. Strategic Management: Competitiveness and Globalization: Concepts, 1st ed.; West Publishing Company: Cleveland, OH, USA, 1995.

72. Sirmon, D.G.; Hitt, M.A.; Ireland, R.D. Managing firm resources in dynamic environments to create value: Looking inside the black box. Acad. Manag. Rev. 2007, 32, 273-292. [CrossRef]

73. McCallum, S.; O'Connell, D. Social capital and leadership development: Building stronger leadership through enhanced relational skills. Leadersh. Organ. Dev. J. 2009, 30, 152-166. [CrossRef]

74. Bontis, N. Intellectual capital: An exploratory study that develops measures and models. Manag. Decis. 1998, 36, 63-76. [CrossRef]

75. Stewart, T.A. Intellectual Capital: The New Wealth of Organization, 1st ed.; A Currency Book; Crown Publishing Group: New York, NY, USA, 1997. 
76. Birasnav, M.; Rangnekar, S.; Dalpati, A. Transformational leadership and human capital benefits: The role of knowledge management. Leadersh. Organ. Dev. J. 2011, 32, 106-126. [CrossRef]

77. Ulrich, D.; Zenger, J.H.; Smallwood, W.N. Results-Based Leadershi, 1st ed.; Harvard Business School Press: Boston, MA, USA, 1999.

78. Bontis, N.; Serenko, A. A causal model of human capital antecedents and consequents in the financial services industry. J. Intellect. Cap. 2009, 10, 53-69. [CrossRef]

79. Bart, C.K. Measuring the mission effect in human intellectual capital. J. Intellect. Cap. 2001, 2, 320-330. [CrossRef]

80. Ballout, H.I. Career success: The effects of human capital, person-environment fit and organizational support. J. Manag. Psychol. 2007, 22, 741-765. [CrossRef]

81. Dizgah, M.R.; Alipour, H.R.; Chegini, M.G.; Falahati, A. Human capital characteristics and organizational performance. Aust. J. Basic Appl. Sci. 2011, 5, 803-809.

82. Au, A.K.M.; Altman, Y.; Roussel, J. Employee training needs and perceived value of training in the Pearl River Delta of China: A human capital development approach. J. Eur. Ind. Train. 2008, 32, 19-31. [CrossRef]

83. Wayne, S.J.; Liden, R.C.; Kraimer, M.L.; Graf, I.K. The role of human capital, motivation and supervisor sponsorship in predicting career success. J. Organ. Behav. 1999, 20, 577-595. [CrossRef]

84. Motley, A. Leadership for the Long Haul. Business Officer Magazine, 2007.

85. Harley, B. The myth of empowerment: Work organisation, hierarchy and employee autonomy in contemporary Australian workplaces. Work. Employ. Soc. 1999, 13, 41-66. [CrossRef]

86. Landau, L. Humanan Capital Development and Its Impact on Firm Performance: Evidence from Developmental Economics. J. Int. Soc. Res. 2009, 2, 60-67.

87. Hamadamin, H.H.; Atan, T. The impact of strategic human resource management practices on competitive advantage sustainability: The mediation of human capital development and employee commitment. Sustainability 2019, 11, 5782. [CrossRef]

88. Balkundi, P.; Kilduff, M. The ties that lead: A social network approach to leadership. Leadersh. Q. 2006, 17, 419-439. [CrossRef]

89. Prusak, L.; Cohen, D. How to invest in social capital. Harv. Bus. Rev. 2001, 79, 86-93, 147. [PubMed]

90. Adler, P.S.; Kwon, S.W. Social capital: Prospects for a new concept. Acad. Manag. Rev. 2002, 27, 17-40. [CrossRef]

91. Nahapiet, J.; Ghoshal, S. Social capital, intellectual capital, and the organizational advantage. Acad. Manag. Rev. 1998, 23, 242-266. [CrossRef]

92. Hitt, M.A.; Dacin, M.T.; Levitas, E.; Arregle, J.L.; Borza, A. Partner selection in emerging and developed market contexts: Resource-based and organizational learning perspectives. Acad. Manag. J. 2000, 43, 449-467. [CrossRef]

93. Edmonstone, J. Developing leaders and leadership in health care: A case for rebalancing? Leadersh. Heal. Serv. 2011, 24, 8-18. [CrossRef]

94. Hartley, J.; Martin, J.; Benington, J. Leadership in Healthcare: A Review of the Literature for Health Care Professionals, Managers and Researchers; Institute of Governance \& Public Management, University of Warwick: Coventry, UK, 2008.

95. Day, D.; Harrison, M. A multilevel, identity-based approach to leadership development. Hum. Resour. Manag. Rev. 2007, 17, 360-373. [CrossRef]

96. Nemanick, R. Building the social capital of leaders. Leadersh. Eff. 2007. Available online: https://leadership-effect.com/articles/ building-the-social-capital-of-leaders/ (accessed on 6 July 2021).

97. Raelin, J.A.; Coghlan, D. Developing Managers as Learners and Researchers: Using Action Learning and Action Research. J. Manag. Educ. 2006, 30, 670-689. [CrossRef]

98. Ellinger, A.E.; Baş, A.B.E.; Ellinger, A.D.; Wang, Y.L.; Bachrach, D.G. Measurement of organizational investments in social capital: The service employee perspective. J. Bus. Res. 2011, 64, 572-578. [CrossRef]

99. Boal, K.B.; Schultz, P.L. Storytelling, time, and evolution: The role of strategic leadership in complex adaptive systems. Leadersh. Q. 2007, 18, 411-428. [CrossRef]

100. Liu, P.L.; Chen, W.C.; Tsai, C.H. An empirical study on the correlation between knowledge management capability and competitiveness in Taiwan's industries. Technovation 2004, 24, 971-977. [CrossRef]

101. Hong, H.K.; Kim, J.S.; Kim, T.; Leem, B.H. The effect of knowledge on system integration project performance. Ind. Manag. Data Syst. 2008, 108, 385-404. [CrossRef]

102. Zuckerman, A.; Buell, H. Is the world ready for knowledge management? Qual. Prog. 1998, 31, 81-84.

103. Walczak, S. Organizational knowledge management structure. Learn. Organ. 2005, 12, 330-339. [CrossRef]

104. Albers, J.A.; Brewer, S. Knowledge management and the innovation process: The eco-innovation model. J. Knowl. Manag. Pract. 2003, 4, 1-6.

105. Seemann, P.; De Long, D.; Stucky, S. Building intangible assets: A strategic framework for investing in intellectual capital. In Knowledge Management: Classic and Contemporary Works; Morey, D., Maybury, M.T., Thuraisingham, B., Maybury, M., Eds.; MIT Press: Cambridge, MA, USA, 2002; pp. 1-17.

106. Drucker, P. Post-Capitalist Society, 1st ed.; HarperBusiness: New York, NY, USA, 1993.

107. Daud, S.; Fadzilah, W.; Yusoff, W. Knowledge Management and Firm Performance in SMEs: The Role of Social Capital as a mediating Variable. Asian Acad. Manag. J. 2010, 15, 135-155.

108. Von Krogh, G. Care in knowledge creation. Calif. Manag. Rev. 1998, 40, 133-153. [CrossRef]

109. Bollinger, A.S.; Smith, R.D. Managing organizational knowledge as a strategic asset. J. Knowl. Manag. 2001, 5, 8-18. [CrossRef] 
110. Leyland, L.; Ogilvie, O. Things are not always what they seem: How reputations, culture, and incentives influence knowledge transfer. Learn. Organ. 2006, 13, 7-24. [CrossRef]

111. Alavi, M.; Leidner, D.E. Review: Knowledge management and knowledge management systems: Conceptual foundations and research issues. MIS Q. 2001, 25, 107-136. [CrossRef]

112. Okunoye, A.; Bertaux, N. Addressing contextual issues in knowledge management: A guiding framework. In Current Issues in Knowledge Management; Jennex, I.M., Ed.; IGI Global: Hershey, PA, USA, 2008; pp. 12-33.

113. Gandhi, S. Knowledge management and reference services. J. Acad. Librariansh. 2004, 30, 368-381. [CrossRef]

114. Mertins, K.; Heisig, P.; Vorbeck, J. Knowledge Management Best Practice in Europe, 1st ed.; Springer: Berlin/Heidelberg, Germany, 2001.

115. Al-Alawi, A.I.; Al-Marzooqi, N.Y.; Mohammed, Y.F. Organizational culture and knowledge sharing: Critical success factors. J. Knowl. Manag. 2007, 11, 22-42. [CrossRef]

116. Sun, Z.; Hao, G. HSM: A hierarchical spiral model for knowledge management. In Proceedings of the 2nd International Conference on Information Management and Business, Sydney, Australia, 13-16 February 2006; pp. 542-551.

117. Heisig, P.; Vorbeck, J. Benchmarking survey results. In Knowledge Management Best Practices in Europe; Mertins, K., Heisig, P., Vorbeck, J., Eds.; Springer: Berlin/Heidelberg, Germany, 2001; pp. 97-123.

118. Davenport, T.H.; Prusak, L. Working Knowledge: How Organizations Manage What They Know; Harvard Business School Press: Cambridge, MA, USA, 1998.

119. Coakes, E. Knowledge Management: Current Issues and Challenges; Idea Group Inc (IGI), IRM Press: London, UK, 2003.

120. Tyler, K.; Bibri, M.; Tyler, N. Strategic Sustainable Development and Knowledge Management the Aatural Step: A Case Study in Knowledge Management from a Backcasting Perspective Introduction. Master's Thesis, School of Mechanical Engineering Blekinge Institute of Technology, Karlskrona, Sweden, 2007.

121. Small, C.T.; Sage, A.P. Knowledge management and knowledge sharing: A review. Knowl. Manag. $2006,5,153-169$.

122. Vorbeck, J.; Finke, I. Motivation and competence for knowledge management. In Knowledge Management Best Practice in Europe; Mertins, K., Heisig, P., Vorbeck, J., Eds.; Springer: Berlin/Heidelberg, Germany, 2001; pp. 37-56.

123. Chua, A. Knowledge management system architecture: A bridge between KM consultants and technologists. Int. J. Inf. Manag. 2004, 24, 87-98. [CrossRef]

124. Shin, M. A framework for evaluating economics of knowledge management systems. Inf. Manag. 2004, 42, 179-196. [CrossRef]

125. Supyuenyong, V.; Islam, N.; Kulkarni, U. Influence of SME characteristics on knowledge management processes: The case study of enterprise resource planning service providers. J. Enterp. Inf. Manag. 2009, 22, 63-80. [CrossRef]

126. Bartol, K.M.; Srivastava, A. Encouraging Knowledge Sharing: The Role of Organizational Reward Systems. J. Leadersh. Organ. Stud. 2002, 9, 64-76. [CrossRef]

127. Holste, J.; Fields, D. Trust and tacit knowledge sharing and use. J. Knowl. Manag. 2010, 14, 128-140. [CrossRef]

128. Lee, C.L.; Lu, H.P.; Yang, C.; Hou, H.T. A process-based knowledge management system for schools: A case study in Taiwan. Turkish Online J. Educ. Technol. 2010, 9, 10-21.

129. Nesheim, T.; Olsen, K.M.; Tobiassen, A.E. Knowledge communities in matrix-like organizations: Managing knowledge towards application. J. Knowl. Manag. 2011, 15, 836-850. [CrossRef]

130. Rumelt, R. Towards a strategic theory of the firm. In Resources, Firms, and Strategies: A Reader in the Resource-Based Perspective; Foss, N.J., Ed.; Prentice-Hall: Englewood Cliffs, NJ, USA, 2003; pp. 556-570.

131. Mahoney, J.; Pandian, J. The resource based view within the conversation of strategic management. Strateg. Manag. J. 1992, 13, 363-380. [CrossRef]

132. Amit, R.; Schoemaker, P.J.H. Strategic assets and organizational rent. Strateg. Manag. J. 1993, 14, 33-46. [CrossRef]

133. El Shafeey, T.; Trott, P. Resource-based competition: Three schools of thought and thirteen criticisms. Eur. Bus. Rev. 2014, 26, 122-148. [CrossRef]

134. Kraaijenbrink, J.; Spender, J.-C.; Groen, A.J. The resource-based view: A review and assessment of its critiques. J. Manag. 2010, 36, 349-372. [CrossRef]

135. Hafeez, K.; Zhang, Y.B.; Malak, N. Core competence for sustainable competitive advantage: A structured methodology for identifying core competence. IEEE Trans. Eng. Manag. 2002, 49, 28-35. [CrossRef]

136. Jones, G.R. Organizational Theory, Design, and Change, 7th ed.; Prentice Hall: Upper Anhe, NJ, USA, 2007.

137. Newbert, S. Value, rareness, competitive advantage, and performance: A conceptual level empirical investigation of the resource based view of the firm. Strateg. Manag. J. 2008, 29, 745-768. [CrossRef]

138. Kogut, B.; Zander, U. Knowledge of the firm, combinative capabilities, and the replication of technology. Organ. Sci. 1992, 3, 383-397. [CrossRef]

139. Henderson, R.; Cockburn, I. Measuring competence? Exploring firm effects in pharmaceutical research. Strateg. Manag. J. 1994, 15, 63-84. [CrossRef]

140. Carmeli, A.; Cohen, A. Organizational reputation as a source of sustainable competitive advantage and above-normal performance: An empirical test among local authorities in Israel. Public Adm. Manag. Interact. J. 2001, 6, 122-165.

141. Cooper, C.L.; Argyris, C. The blackwell encyclopedic dictionary of strategic management. In The Blackwell Encyclopedia of Management and Encyclopedic Dictionaries; Channon, D.F., Ed.; Blackwell Encyclopedia of Management; Wiley-Blackwell: Hoboken, NJ, USA, 1999. 
142. Polanyi, M. The Tacit Dimension, 1st ed.; Routledge \& Kegan Paul: London, UK, 1966.

143. Huseman, R.C.; Goodman, J.P. Leading with Knowledge: The Nature of Competition in the 21st Century; Sage Publications: New York, NY, USA, 1999.

144. Nonaka, I. Dynamic theory knowledge of organizational creation. Organ. Sci. 1994, 5, 14-37. [CrossRef]

145. Nonaka, I.; Toyama, R. The knowledge-creating theory revisited: Knowledge creation as a synthesizing process. Knowl. Manag. Res. Pract. 2003, 1, 2-10. [CrossRef]

146. Hagen, A.F.; Hassan, M.T.; Amin, S.G. Critical strategic leadership components: An empirical investigation. Management 1998, $63,39$.

147. Martin, J.S.; Marion, R. Higher education leadership roles in knowledge processing. Learn. Organ. 2005, 12, 140-151. [CrossRef]

148. Leitch, B.J.M.; Rosen, P.W. Knowledge management, CKO, and CKM: The keys to competitive advantage. Manchester Rev. 2001, 6, 9-13.

149. Bou-Llusar, J.C.; Segarra-Ciprés, M. Strategic knowledge transfer and its implications for competitive advantage: An integrative conceptual framework. J. Knowl. Manag. 2006, 10, 100-112. [CrossRef]

150. Robbins, S.; Judge, T. Organizational Behavior, 15th ed.; Pearson Education, Inc.: Hoboken, NJ, USA, 2013.

151. Lakshman, C. Organizational knowledge leadership: A grounded theory approach. Leadersh. Organ. Dev. J. 2007, 28, 51-75. [CrossRef]

152. Jaakkola, E. Designing conceptual articles: Four approaches. AMS Rev. 2020, 10, 18-26. [CrossRef]

153. Meredith, J. Theory Building through Conceptual Methods. Int. J. Oper. Prod. Manag. 1993, 13, 3-11. [CrossRef]

154. MacInnis, D.J. A Framework for Conceptual Contributions in Marketing. J. Mark. 2011, 75, 136-154. [CrossRef]

155. Hirschi, G.; Jones, M. Strategic leadership: A resourced based view. MIBES Trans. 2008, 60-74. Available online: http: //mibes.teithessaly.gr/proceedings/2008/oral/Hirshi_Jones.pdf (accessed on 6 July 2021).

156. Sharkie, R. Knowledge creation and its place in the development of sustainable competitive advantage. J. Knowl. Manag. 2003, 7, 20-31. [CrossRef]

157. Adams, G.L.; Lamont, B.T. Knowledge management systems and developing sustainable competitive advantage. J. Knowl. Manag. 2003, 7, 142-154. [CrossRef]

158. Chuang, S.-H. A resource-basedperspective on knowledgemanagementcapability and competitive advantage: An empiricalinvestigation. Expert Syst. Appl. 2004, 27, 459-465. [CrossRef]

159. Alflrević, N.; Račić, D. Knowledge integration as a source of competitive advantage in large Croatian enterprises. Proc. J. Univers. Comput. Sci. 2004, 10, 712-722.

160. Gold, A.H.; Malhotra, A.; Segars, A.H. Knowledge management: An organizational capabilities perspective. J. Manag. Inf. Syst. 2001, 18, 185-214. [CrossRef]

161. Nonaka, I.; Toyama, R.; Konno, N. SECI, Ba and Leadership: A Unified Model of Dynamic Knowledge Creation. Long Range Plann. 2000, 33, 5-34. [CrossRef]

162. Fernandes, I.B.; Gonzalez, A.; Sabherwal, R. Knowledge Management: Challenges, Solutions and Technologies, 1st ed.; Pearson Prentice Hall. Inc.: Hoboken, NJ, USA, 2004.

163. Burt, R.S. Neighbor Networks: Competitive Advantage Local and Personal, 1st ed.; Oxford University Press: Oxford, UK, 2010.

164. Hitt, M.A.; Keats, B.W.; Yucel, E. Strategic leadership in global business organizations: Building trust and social capital. Adv. Glob. Leadersh. 2003, 3, 9-35.

165. Joia, L.A.; Lemos, B. Relevant factors for tacit knowledge transfer within organisations. Proc. J. Knowl. Manag. 2010, 14, 410-427. [CrossRef]

166. Chen, L.; Mohamed, S. The strategic importance of tacit knowledge management activities in construction. Constr. Innov. 2010, 10, 138-163. [CrossRef]

167. Vandaie, R. The role of organizational knowledge management in successful ERP implementation projects. Knowledge-Based Syst. 2008, 21, 920-926. [CrossRef]

168. Yahya, S.; Goh, W.-K. Managing human resources toward achieving knowledge management. J. Knowl. Manag. 2002, 6, 457-468. [CrossRef]

169. Spencer, J.W. Firms' knowledge-sharing strategies in the global innovation system: Empirical evidence from the flat panel display industry. Strateg. Manag. J. 2003, 24, 217-233. [CrossRef]

170. Grant, R.M. Toward a knowledge-based theory of the firm. Strateg. Manag. J. 1996, 17, 109-122. [CrossRef]

171. Sekaran, U.; Bougie, R. Research Methods for Business: A Skill Building Approach, 5th ed.; John Wiley \& Sons: Hoboken, NJ, USA, 2010.

172. Sekaran, U. Research Methods for Business: A Skill Building Approach, 4th ed.; John Wiley \& Sons Inc.: Hoboken, NJ, USA, 2003.

173. Sinclair, M. A guide to understanding theoretical and conceptual frameworks. Evid. Based Midwifery 2007, 5, 39.

174. Schiuma, G.; Carlucci, D.; Lerro, A. Managing knowledge processes for value creation. VINE J. Inf. Knowl. Manag. Syst. 2012, 42, 4-14. [CrossRef]

175. Mahdi, O.R.; Almsafir, M.K.; Yao, L. The role of knowledge and knowledge management in sustaining competitive advantage within organizations: A review. Afr. J. Bus. Manag. 2011, 5, 9912-9931. [CrossRef]

176. Porter, M. Competitive Advantage: Creating and Sustaining Superior Performance with a New Introduction; Free Press: New York, NY, USA, 1985. 
177. Bryant, S.E. The role of transformational and transactional leadership in creating, sharing and exploiting organizational knowledge. J. Leadersh. Organ. Stud. 2003, 9, 32-44. [CrossRef]

178. Lee, Y.; Lee, S. Capabilities, processes, and performance of knowledge management: A structural approach. Hum. Factors Ergon. Manuf. 2007, 17, 21-41. [CrossRef] 